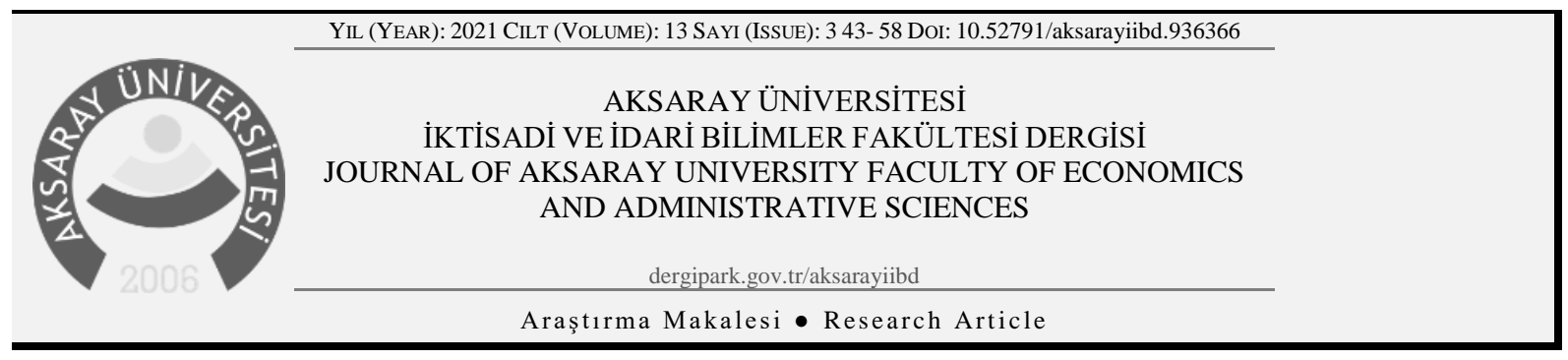

\title{
İşletme Yönetimi Önlisans Programlarında Okutulan Zorunlu Derslerde Muhasebe ve Finans Derslerinin A ğırlığı Üzerine Bir Araştırma
}

\author{
A Research On The Weight of Accounting and Finance Courses in Compulsory Courses in \\ Business Management Associate Programs
}

Çăgatay Mirgen ${ }^{1}$ ve Süleyman Emir ${ }^{2}$

${ }^{1}$ Öğr.Gör., Milli Savunma Üniversitesi, KAMYO, İşletme Yönetimi Bölümü, cmirgen@msu.edu.tr, Orcid ID: 0000-0002-0970-0121

${ }^{2}$ Ö̆gr.Gör., Milli Savunma Üniversitesi, KAMYO, İsletme Yönetimi Bölümü, semir@msu.edu.tr, Orcid ID: 0000-0002-3873-2712

M A K A LE B İL G İ İ

Anahtar Kelimeler

Muhasebe ve Finans Dersleri,

Ön Lisans Ë̆itimi,

Işsetme Yönetimi Bölümü

\section{Makale Geçmişi:}

Geliş Tarihi: 11 Mayıs 2021

Kabul Tarihi: 29 Ağustos 2021

\section{A R T I C LEINFO}

\section{Keywords}

Accounting and Finance Courses,

Business Administration,

Associate Degree Program

\section{Article History:}

Received: 11 May 2021

Accepted: 29 August 2021

\section{Ö ZET}

Bir bilgi sistemi olan muhasebe ve finans, karar alıcıların doğru bilgilere ulaşmasında büyük bir önem arz etmektedir. Bu önemin bir gereği olarak, muhasebe ve finansa ilişkin işlemlerin doğru bir şekilde kavranması ve uygulanabilmesi için kaliteli bir eğitim sistemi oluşturmak gerekmektedir. Bu çalışmada, işletme yönetimi önlisans bölümlerinde okutulan zorunlu dersler tespit edilerek bu derslerde muhasebe ve finans derslerinin ağıllığının saptanması amaçlanmıştır. Bu kapsamda, Türkiye'deki 64 devlet ve 9 vakıf üniversitesinin işletme yönetimi önlisans programlarına ait ders programları toplanarak sınıflandırılmış ve analize uygun hale getirilerek ders ve ders saatlerinin frekans dağılımları belirlenmiştir. Sonuç olarak, işletme yönetimi önlisans programlarında dört öğrenim döneminde de en çok okutulan derslerin muhasebe ve finans alanına ait derslerden oluştuğu tespit edilmiştir.

\begin{abstract}
A B S T R A C T
Accounting and finance, which is an information system, is of great importance for decision makers to access correct information. As a requirement of this importance, it is necessary to establish a quality education system in order to understand and apply the accounting and financial transactions correctly. In this study, it is aimed to determine the weight of accounting and finance courses in these courses by determining the compulsory courses taught in business administration associate degree departments. In this context, business management of 64 state and 9 foundation universities in Turkey of their degree program courses are collected. Then, the frequency distributions of the lessons and lesson hours made suitable for analysis were determined. As a result, it has been determined that the most taught courses in business management associate degree programs in all four education terms consist of courses in the field of accounting and finance.
\end{abstract}

Y irmi birinci yüzyll, ticari kuruluş ve endüstriler için büyük bir değişim dönemi olmuştur. Bu değişim, sadece geleneksel konularda bilgili ve teknik beceriye sahip olmanın yeterli olmadığını, aynı zamanda bireysel iş becerilerine sahip bireylere olan ihtiyacın daha fazla olduğunu göstermiştir. Bu doğrultuda, doğru, etkin ve kaliteli bilgiye zamanında ulaşmak küreselleşen dünyada önemli bir konu haline gelmiştir.

Dünyada ekonomik açıdan gelişmiş, bilimsel çalışmaların yapıldığı ve eğitimde gelişimin sağlanabilmesi için arayış içesinde olan ülkelerde, üzerinde kafa yorulan eğitim programlarından birisi işletme bölümleridir. İşletme eğitiminin kökleri Amerika Birleşik Devletleri (ABD)'ne dayanmaktadır. Bugün, Amerika'da İşletme alanında eğitim veren çok sayıda kurum/kuruluş bulunmaktadır (Teker, 1998: 14). Avrupa'da da buna benzer bir durum söz konusu olmakla beraber, işletme bölümlerinde okutulan dersler ve bu derslerin içerikleri Amerikan literatüründen türetilmiş durumdadır (Yüksel, 1998: 15). Türkiye'de ise, Cumhuriyet öncesi yıllarda ilk ticaret yüksek okulu 1881'de Fransa'daki "Ecole des Hautes Etudes Commerciales" model 
alınarak İstanbul'da kurulmuştur (Kipping, Üsdiken ve Puig, 2004: 100). İşletme eğitimi ilerleyen yıllarda, Hitlerin yönetimi altında bulunan Almanya'dan kaçan bazı yabancı bilim adamları tarafından başlatılmıştır. Bu dönemde, Türk üniversitelerinde görev alan çok sayıda Alman profesör olmuştur. Dolayısıyla Türkiye'de işletme eğitiminin başladığı ilk yıllarda Alman ekolü hakimken, 1960'lı yıllarda bu ekol kendini Amerikan ekolüne bırakmıştır (Yüksel, 1998: 15). Ayrıca, Türkiye'de 1936 yılında “İstanbul Üniversitesi İktisat Fakültesi”nin kurulması (Cumhuriyet öncesinde bu eğitim kurumu İstanbul Darülfünun olarak adlandırılmaktayd1) ve 1937 yılında basılarak yayınlanan, "Genel İşletme Ekonomisi” kitabı İşletme eğitimi için önemli yap1 taşları olmuştur (Üsdiken, 2003: 127). Ek olarak bu yıllarda İstanbul Üniversitesi, devlet kurumu kimliğiyle lisans düzeyinde eğitim vermekteydi (Sargut, 2009: 52). 1968'li yıllara gelindiğinde ise, İstanbul Üniversitesi bünyesi altında doğrudan işletme eğitimi vermek amaciyla İşletme Fakültesi kurulmuştur (Üsdiken, 2003: 128).

Geçmişten günümüze gelinceye kadar birçok değişim ve gelişim geçiren işletme alanı, bireylerin iş sahasında yapacağı temel faaliyetlere odaklanacak şekilde bölümlere ayrılmaya başlamıştır. Bu bölümler arasında, bir bilgi sistemi olan muhasebe ve finans, karar alıcıların doğru bilgilere ulaşmasında büyük bir önem arz etmektedir. Bu önemin bir gereği olarak, muhasebe ve finansa ilişkin işlemlerin doğru bir şekilde kavranması ve uygulanabilmesi için kaliteli bir eğitim sistemi oluşturmak gerekmektedir. Günümüzde "Muhasebe ve Finans" alanına ait olan dersler, dünyanın birçok üniversitesinde farklı bölümler altında okutulmaktadır. Böylece, eskiden daha çok işletme bölümlerinde alt bir bilim dalı olarak yer alan muhasebe ve finansman bölümü, günümüzde tek başına bir bilim dalı haline gelmiştir. Muhasebe ve finans alanında lisans ve lisansüstü düzeyde eğitim veren pek çok üniversite bulunmasına rağmen, farklı bölümlerde muhasebe ve finans alanına ait dersleri okutan bölümler de bulunmaktadır. Muhasebe ve finans dersleri bulunan ülke ve üniversitelerde, söz konusu derslerin içerik, düzey ve kalitesi bakımından birçok farklılık bulunmaktadır. Hiç şüphesiz ki bunun altında, ülkelerin muhasebe ve finans sistemleri arasında farklılıklar bulunması yatmaktadır. Çünkü muhasebe ve finans alanı, durağan olmayan içerisinde bulunduğu çevre, ekonomi ve kültüre göre sürekli olarak gelişmekte ve değişmektedir (Ünal ve Doğanay, 2009: 118). Bu sürekli gelişim ve değişim, muhasebe ve finans alanını, işletmecilikte, iş dünyasında, mesleki hayatta, yatırım kararlarında ve daha pek çok konuda aranan bir bilim dalı haline getirmiştir. Muhasebe ve finans alanına olan bu ilgi, bu alana ait derslerin farklı bölümlerde okutulmasını sağlamıştır. Bu bölümler arasında İşletme başı çeken bölümlerden birisidir. Ayrıca, muhasebe ve finans derslerine olan ilginin zamanla daha da artması sonucunda, işletme alanında ön lisans düzeyinde eğitim veren "İşletme Yönetimi” gibi Meslek Yüksek Okulu bölümleride muhasebe ve finans derslerine ağırlık vermeye başlamışlardır. Türkiye'deki üniversitelerde, muhasebe ve finans derslerinin ağırlı̆ııın artmasında ulusal ve uluslararası standartlarla düzenlenmiş ders programlarının olması büyüktür. Ders programlarının bilimsel olarak yeterli olup olmadığı, verilen eğitimin kalitesine doğrudan etki etmektedir (Zaif ve Ayanoğlu, 2007: 117). Ayrıca, günümüzde İşletme yönetimi bölümünde yer alan dersler, kullanılan öğretim yöntemleri ve öğrencilerin öğrenme süreçleri önemli birer konu haline gelmiştir (Brown ve Rich, 2020: 84). Bu noktada, işletme bölümlerine ait derslerin uygun bir şekilde ayarlanarak, yeniliklere açık olması sağlanmalıdır.

Bu çalışmada, Türkiye'de “İşletme Yönetimi Bölümü” adı altında eğitim veren önlisans meslek yüksek okullarının ders programları incelenmiş ve bu ön lisans bölümlerinde verilen muhasebe ve finans derslerinin neler olduğu, ders saatleri ve ders sayıları tespit edilmeye çalışılmıştır. Çalışmada elde edilen bulgular, çalışmanın yapıldığı 2021 yılına ve İşletme Yönetimi önlisans bölümlerine aittir.

\section{LITERATÜR TARAMASI}

Çalışmanın konusuyla ilgili çok fazla çalışma bulunmamasına rağmen, farklı alanları ele alan çalışmalar bulunmaktadır. Çalışmanın konusuna benzer nitelik gösteren çalışmalar aşağıda paragraflar halinde ifade edilmiştir.

Miah ve Solomonides (2021) çalışmalarında, yeni bir işletme yüksek lisans programının kavramsallaştırılması ve tasarımı için çağdaş uygulama ihtiyacını belirlemeye ve bir Avustralya üniversitesinde yeni endüstri beklentilerini dikkate alan bir program oluşturmayı amaçlamaktadırlar. Bu doğrultuda, beş kıdemli veri analitiği uzmanıyla açık uçlu görüşmeler yapmışlardır. Ortaya çıkan sonuçlar, açık kaynaklı araçlara dayalı genel teknik bilginin, belirli endüstri sertifikalarının veya özel becerilerin, teknoloji entegrasyon bilgisinin, pazarlama bilgisinin, proje yönetiminin ve karar vermenin önemli unsurlar olduğunu göstermiştir. Bu bulgulara dayanarak çalışmada, temel öğrenme hedefleri, programın ilk yapısı ve uzmanlık konularıyla ilgili öneriler sunulmuştur. Ayrıca, yüksek öğrenimde yeni uygulamalı dersler oluşturulması gerektiği de ifade edilmiştir.

Heilporn ve Desrochers (2020) çalışmalarında, öğrencilerin öğrenmesini desteklemek için online matematik dersi veren bir işletme fakültesini ele almışlardır. Bu ders öğrencilerin her hafta katılabilecekleri ek dersleri de içermektedir. Çalışmada bu dersin beş yarıyıl boyunca eğitimini alan öğrencilerin yorumları, sistem içeriğinin analizi ve dersin yapılış şeklinin öğrenmeye yaptı̆̆ katkı değerlendirilmeye çalışılmıştır. Çalışma sürecinin sonunda, öğrenciler öğretim elemanının dönem boyunca varlığının ve dersi takip etmesinin öğrenme süreçlerini olumlu yönde etkilediğini belirtmişlerdir. Ayrıca, öğrencilerin büyük çoğunluğu, ders sistemiyle ilgili diğer unsurlar hakkında da olumlu yorumlarda bulunmuşlardır. 
Brown ve Rich (2020) çalışmalarında, işletme okullarında uygulanan programların mevcut durumunu değerlendirmektedir. Çalışmada öğrencilerin geribildirimlerinden yararlanılmıştır. "City's Business School"daki işletme yönetimi bölümünün yeniden tasarımı bir vaka örneği kullanılarak değerlendirilmiştir. Öğrenciler geribildirim yoluyla, yeniden tasarlanan programda başarı durumlarını değerlendirmişlerdir. Ayrıca, çalışmada işletme okullarında kullanılan değerlendirme yöntemlerinin yapılan değişikliklerden etkilenme düzeyleri de tartışılmıştır.

Terzi, Şen ve Solak (2013) çalışmalarında, 2012-2013 yılları arasında üniversitelerin Bologno programı için hazırlamış oldukları işletme bölümüne ait ders programlarının muhasebe eğitimi üzerindeki etkisini ölçmek istemişlerdir. Bu amaçla, Türkiye'deki İşletme bölümlerinin ders programlarını inceleyerek, üniversitelerin ders kredileri ve AKTS'lerini içeren bir liste hazırlamışlar ve karşılaştırma yapmışlardır. Yapılan karşılaştırma sonucunda, devlet üniversitelerinde okutulan muhasebe derslerinin, vakıf üniversitelerine göre sayısal olarak daha fazla olduğu ve bu durumun devlet üniversitelerinde daha kapsamlı bir muhasebe eğitimi verildiği anlamına gelebileceğini ifade etmişlerdir. Fakat, çok daha kesin yargılara varabilmek için muhasebe dersini veren öğretim elemanlarının sayısı, tecrübesi, dersin verildiği mekân vb. gibi faktörlerinde dikkate alınması gerektiğini belirtmişlerdir. Ek olarak, çalışma sonucunda Türkiye'de Bologna programının henüz oturmamış olduğu da söylenmiştir.

Özkul (2012) çalışmasında, Türkiye'deki işletme eğitiminin tarihsel gelişimiyle ilgili bir derleme yapmış ve 19.yüzyılda yükseköğretim kurumlarının vermiş olduğu işletme eğitimini değerlendirmiştir. Çalışma sonucunda, geçmişte Türkiye'de işletme eğitimi veren yükseköğretim kurumlarında Fransızcanın zorunlu tutulduğu ve muhasebe kitaplarının Fransızcadan çevrilerek literatür oluşturulduğu ifade edilmiştir.

Subaşı ve Demir (2009) çalışmalarında, muhasebe derslerinin yoğunluk gösterdiği işletme bölümlerinin (Türkiye'deki devlet ve vakıf üniversitelerinin) ders programlarını incelemişler ve okutulan muhasebe derslerinin durum analizini yapmışlardır. Analiz sonucunda, Türkiye'de muhasebe derslerinin 170 farklı isimle ders olarak verildiğini ve devlet üniversitelerinin vakıf üniversitelerine göre zorunlu muhasebe dersleri açısından sayıca fazla olduğunu tespit etmişlerdir. Ayrıca, devlet üniversitelerinde tüm dönemlerde zorunlu muhasebe eğitimi verilirken, vakıf üniversitelerinde daha çok ikinci ve üçüncü dönemlerde zorunlu muhasebe dersleri olduğu ifade edilmiştir.

Zaif ve Ayanoğlu (2007) çalışmalarında, muhasebe dersi veren devlet ve vakıf üniversitelerinin eğitim kalitesine etki eden faktörleri belirlemeye çalışmışlardır. Bu amaçla, muhasebe derslerinin sayısı ve kredisi, derslerin içeriği, modern eğitim araç gereçlerinin kullanımı, eğitim kurumlarının fiziki imkanları gibi unsurlar değerlendirilmiştir. Çalışmada, muhasebe derslerinin kredi ve sayılarının yeterli düzeyde olmasının, eğitim kalitesi açısından olumlu olarak değerlendirilebileceği ifade edilmiştir. Çalışma sonucunda, Türkiye'de üniversiteler arasında muhasebe dersleri açısından farklılıklar bulunduğu, aynı isme sahip derslerin ortak bir kredi ve içeriğe sahip olmadığı tespit edilmiştir. Ayrıca, Türkiye'de Erasmus, Socrates vb. akreditasyon çalışmalarının tüm üniversitelerde tamamlanmamış olduğu ifade edilmiştir.

Yelkikalan ve Pazarcık (2005) çalışmalarında, Türkiye'deki işletme eğitiminin küresel değişimlere ne düzeyde uyum sağladığını belirlemek ve çıkarımlarda bulunmak istemişlerdir. Bu amaçla, Çanakkale Onsekiz Mart Üniversitesi Biga İktisadi ve İdari Bilimler Fakültesi’nin İşletme Bölümü'ne ait 1994-2005 yılları arasındaki ders programları, küresel olarak gelişim gösteren işletme alanıyla karşılaştırılarak değerlendirilmiştir. Çalışma sonucunda, ilgili yıllarda ders programında yapılan değişiklikler, eklenen ve çıkarılan derslere ilişkin açıklamalar yapılmıştır.

Çürük ve Doğan (2001) çalışmasında, gelişmekte olan ülkelerde verilen muhasebe eğitiminin ülke şartlarına uygunluğu ile ihtiyaçlara cevap verme düzeyini tespit eden çalışma sayısının yetersiz olduğunu belirtmiş ve Türkiye'deki üniversitelerin vermiş olduğu muhasebe eğitimlerinin işletmelerin ihtiyaçlarını karşılayıp karşılamadığını değerlendirmek istemişlerdir. Çalışma sonucunda, Türkiye'deki üniversitelerin vermiş olduğu muhasebe eğitiminin işletme taleplerini karşılamadığı yorumu yapılmıştır.

\section{ARASTIRMANIN AMACI VE ÖNEMI}

Muhasebe ve finans önemli bir işletme fonksiyonudur. Bir işletmenin başarılı olabilmesi tüm fonksiyonların işletme amaçları doğrultusunda düzgün ve koordineli bir şekilde yönetilmesine bağlıdır. Muhasebe ve finans yardımıyla elde edilen bilgilerin kullanılabilmesi için de personelin gerekli donanıma sahip olması, ilgili konulara yönelik verilen eğitimden geçmesi gerekmektedir. Bu bağlamda, üniversitelerde okutulan derslerin mesleki hayata geçmeden önce bir alt yapı oluşturması büyük önem arz etmektedir.

Bu çalışmada, Türkiye'deki meslek yüksekokullarının İşletme Yönetimi Bölümlerinde okutulan zorunlu derslerin ve bu dersler içinde muhasebe ve finans derslerinin ağırlığının belirlenmesi amaçlanmıştır. Bu kapsamda, meslek yüksek okullarında verilen zorunlu ders sayılarının ve ders saatlerinin tespit edilmesi, zorunlu dersler içinde muhasebe ve finans derslerinin ağırlığının tespit edilerek işletme yönetimi bölümleri için ilgili derslerin hangi yoğunlukta işlendiği belirlenmeye çalışılmıştır. 


\section{ARAŞTIRMANIN METODOLOJISİ}

\subsection{Araştırmanın Kapsamı ve Sınırları}

Araştırma kapsamında, İşletme Yönetimi Bölümlerine ait ders programlarına ulaşmak için Yüksek Öğretim Kurumu (YÖK) tarafindan hazırlanan önlisans atlasından yararlanılmıș ve ilgili üniversitelerin internet sitelerinden ders programlarına ulaşılmıştır. Buna göre, İşletme Yönetimi Bölümü bulunan 126 adet devlet, 10 adet vakıf üniversitesine ait meslek yüksekokulu bulunmaktadır. Çalışma kapsamına, İkinci Öğretim, Uzaktan Öğretim Programları ve K.K.T.C.'de bulunan bölümler dahil edilmemiştir. Bazı üniversitelerin bünyesinde bulunan farklı meslek yüksek okullarının birçoğunda, İşletme Yönetimi Bölümü’nün olduğu ve aynı üniversite bünyesinde eğitim vermeleri dolayısıyla benzer ders programlarına sahip oldukları gözlemlenmiştir. Bu nedenle, aynı üniversite bünyesinde bulunan meslek yüksek okullarından en fazla iki tanesi analize dahil edilmiştir. Üniversite bazında değerlendirildiğinde ise 63 tane üniversite ve yine 10 tane vakıf üniversitesinde İşletme Yönetimi Bölümü bulunmaktadır. Her üniversiteye ait en az bir İșletme Yönetimi Bölümü analize dahil edilmek istenmesine rağmen, ders programlarına ulaşılamayan iki devlet üniversitesi (Yozgat Bozok Üniversitesi /Sosyal Bilimler MYO ve Munzur Üniversitesi/Tunceli MYO) çalı̧̧a kapsamı dışında bırakılmıştır. Benzer şekilde ders programına ulaşılamayan bir vakıf üniversitesi de değerlendirmeye alınmamıştır. Bazı üniversitelerin ise, iki adet meslek yüksek okulu araştırmaya dahil edilmiştir (Afyon Kocatepe Üniversitesi, Bolu Abant İzzet Baysal Üniversitesi, Düzce Üniversitesi ve Gaziantep Üniversitesi).

Tablo 1. Araştırma Kapsamındaki Devlet Üniversitelerine Ait Meslek Yüksek Okulları

\begin{tabular}{|c|c|}
\hline \multicolumn{2}{|c|}{ Meslek Yüksekokulları (Devlet) } \\
\hline 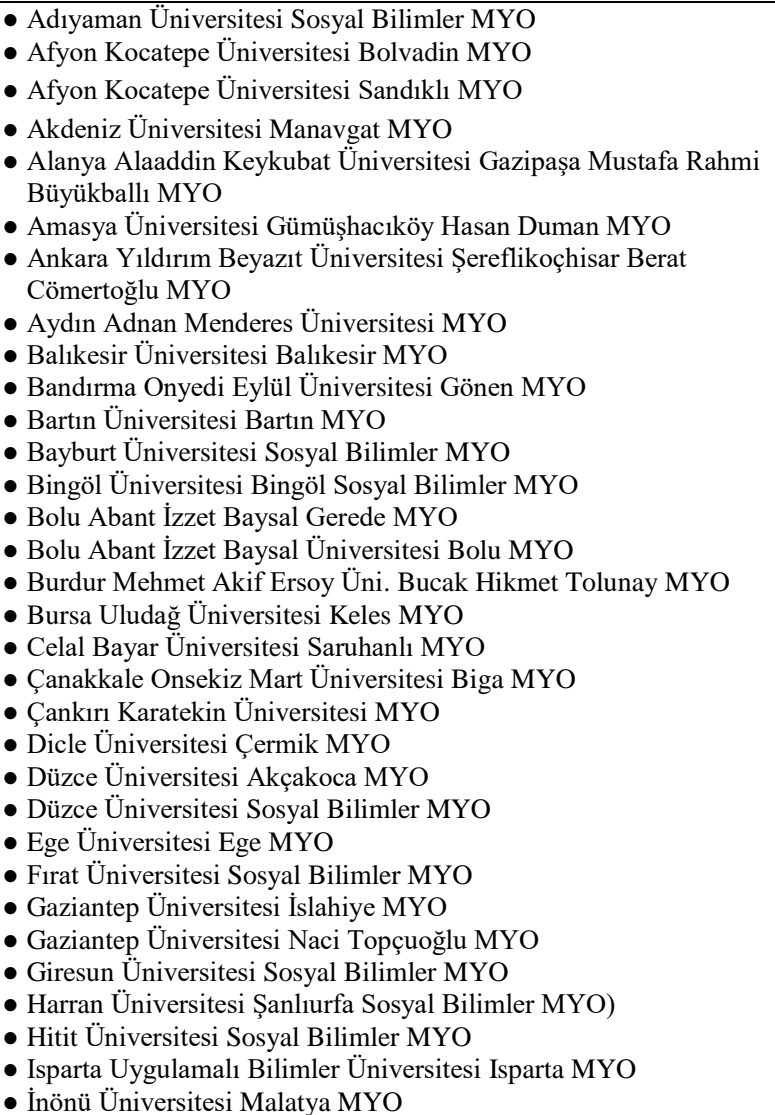 & $\begin{array}{l}\text { - Kafkas Üniversitesi Sosyal Bilimler MYO } \\
\text { - Kahramanmaraş Sütçü İmam Üni. Sosyal Bilimler MYO } \\
\text { - Karabük Üniversitesi Safranbolu MYO } \\
\text { - Kastamonu Üniversitesi MYO } \\
\text { - Kayseri Üniversitesi Sosyal Bilimler MYO } \\
\text { - Kırıkkale Üniversitesi Fatma Şenses Sosyal Bil MYO } \\
\text { - Kırşehir Ahi Evran Üniversitesi Sosyal Bilimler MYO } \\
\text { - Kilis } 7 \text { Aralık Üniversitesi Sosyal Bilimler MYO } \\
\text { - Kütahya Dumlupınar Üniversitesi Kütahya Sos. Bil. MYO } \\
\text { - Malatya Turgut Özal Üniversitesi Akçadağ MYO } \\
\text { - Mardin Artuklu Üniversitesi MYO } \\
\text { - Mersin Üniversitesi Anamur MYO } \\
\text { - Milli Savunma Üniversitesi Kara Astsubay MYO } \\
\text { - Muğla Sitk1 Koçman Üniversitesi Muğla MYO } \\
\text { - Necmettin Erbakan Üniversitesi Seydişehir MYO } \\
\text { - Niğde Ömer Halisdemir Üniversitesi Niğde Sos. Bil. MYO } \\
\text { - Ondokuz Mayıs Üniversitesi Havza MYO } \\
\text { - Ordu Üniversitesi Sosyal Bilimler MYO } \\
\text { - Osmaniye Korkut Ata Üniversitesi Osmaniye MYO } \\
\text { - Pamukkale Üniversitesi Kale MYO } \\
\text { - Recep Tayyip Erdoğan Üniversitesi Sosyal Bil. MYO } \\
\text { - Sakarya Uygulamalı Bil. Üniversitesi Ferizli MYO } \\
\text { - Selçuk Üniversitesi Sosyal Bilimler MYO } \\
\text { - Siirt Üniversitesi Sosyal Bilimler MYO } \\
\text { - Sivas Cumhuriyet Üniversitesi Cumhuriyet Sos. Bil. MYO } \\
\text { - Tekirdağ Namık Kemal Üniversitesi Saray MYO } \\
\text { - Tokat Gaziosmanpaşa Üniversitesi Tokat MYO } \\
\text { - Trabzon Üniversitesi Beşikdüzü MYO } \\
\text { - Trakya Üniversitesi Havsa MYO } \\
\text { - Uşak Üniversitesi Sosyal Bilimler MYO } \\
\text { - Van Yüzüncü Yil Üniversitesi Van MYO } \\
\text { - Zonguldak Bülent Ecevit Üniversitesi Zonguldak MYO }\end{array}$ \\
\hline
\end{tabular}

Araştırma kapsamına dahil edilen devlet üniversitelerine ait meslek yüksekokulları, yukarıdaki Tablo 1.'de gösterilmiştir. Buna göre, 64 devlet üniversitesine ait meslek yüksekokulu araştırma kapsamına alınmıştır.

Tablo 2. Araştırma Kapsamındaki Vakıf Üniversitelerine Ait Meslek Yüksek Okulları

\begin{tabular}{|ll|}
\hline & Meslek Yüksekokulları (Vakıf) \\
\hline - Başkent Üniversitesi (Kahramankazan MYO) & $\bullet$ İstanbul Kültür Üniversitesi (MYO) \\
• Beykent Üniversitesi MYO & $\bullet$ İstanbul Okan Üniversitesi (MYO) \\
• İstanbul Arel Üniversitesi MYO & $\bullet$ Nişantaş1 Üniversitesi (Nişantaşı MYO) \\
• İstanbul Aydın Üniversitesi (Anadolu Bil MYO) & $\bullet$ Ufuk Üniversitesi MYO \\
- İstanbul Esenyurt Üniversitesi (MYO) & \\
\hline
\end{tabular}


Araştırma kapsamına dahil edilen vakıf üniversitelerine ait meslek yüksekokulları, yukarıdaki Tablo 2.'de gösterilmiştir. Buna göre 9 adet vakıf üniversitesine ait meslek yüksekokulu araştırma kapsamına dahil edilmiştir. Bu kapsamda, toplamda 73 devlet ve vakıf üniversitesine ait meslek yüksekokullarının İşletme Yönetimi Bölümü ders programları incelenmiştir.

İşletme Yönetimi Bölümlerinde verilen dersler, meslek yüksekokullarının belirlemiş oldukları müfredata bağlı olarak büyük farklılıklar göstermektedir. Bunun yanında birçok ders içerik olarak aynı veya benzer olmasına rağmen farklı isimlendirilmiştir. Araştırma kapsamında incelenen tüm meslek yüksek okullarında verilen zorunlu derslere ait isimler ise aşağıdaki Tablo 3.'de gösterilmiştir (YÖK Ortak Zorunlu Dersler; Atatürk İlkeleri ve İnkîlap Tarihi, Türk Dili ve Yabancı Dil Dersleri ile Matematik dersleri dahil edilmemiştir).

Tablo 3. Meslek Yüksekokulları İşletme Yönetimi Bölümlerinde Verilen Dersler

\begin{tabular}{|c|c|c|}
\hline 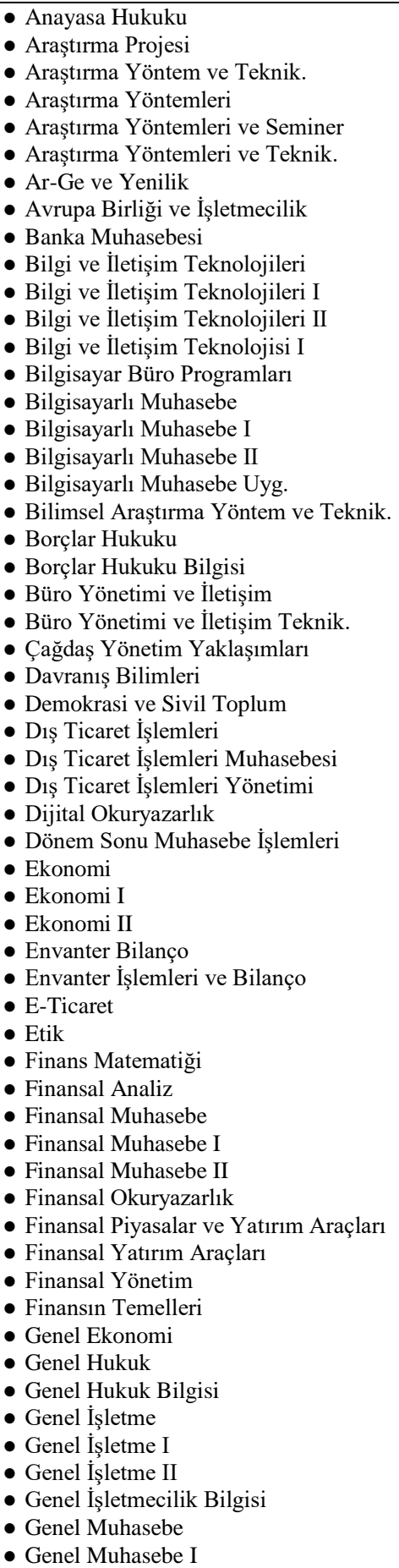 & 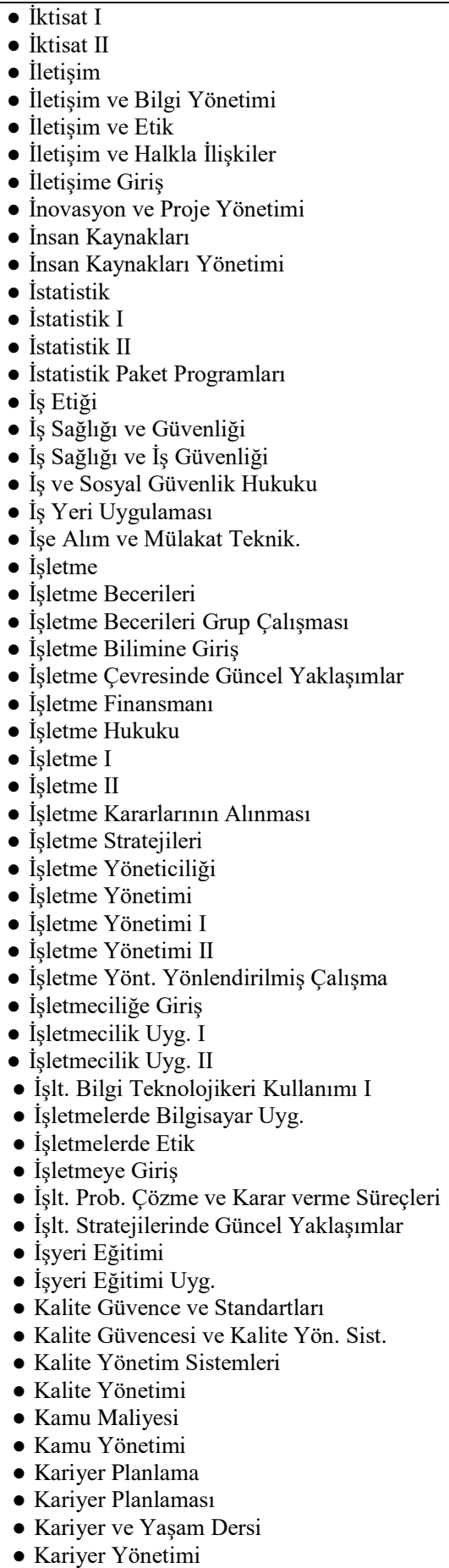 & 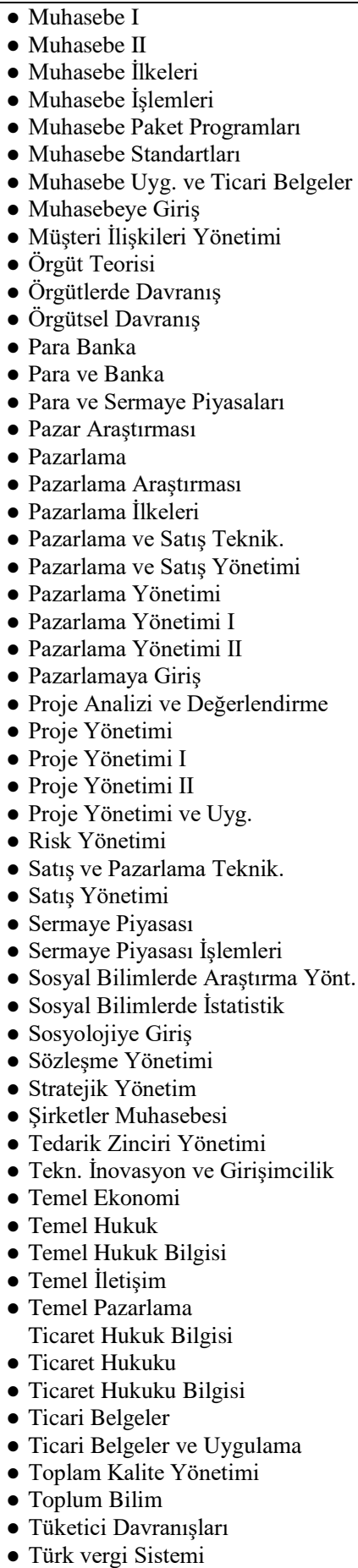 \\
\hline
\end{tabular}




\begin{tabular}{|c|c|c|}
\hline 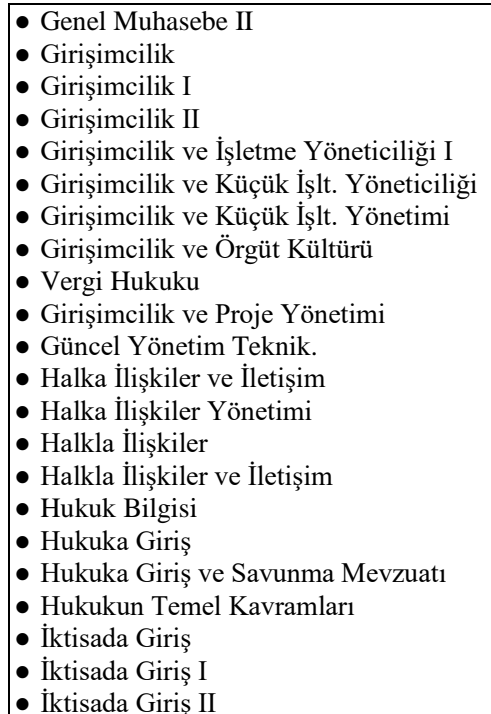 & $\begin{array}{l}\text { - Kiymetli Evrak Hukuku } \\
\text { - Kişisel ve Profesyonel Gelişim } \\
\text { - Kongre ve Fuar Yönetimi } \\
\text { - Kriz Yönetimi } \\
\text { - Kurumsal Yönetim } \\
\text { - Liderlik ve Yönetişim } \\
\text { - Lojistik } \\
\text { - Lojistik Yönetimi } \\
\text { - Makro Ekonomi } \\
\text { - Makro İktisat } \\
\text { - Mali Tablolar Analizi } \\
\text { - Maliyet Analizi } \\
\text { - Maliyet Muhasebesi } \\
\text { - Marka ve Marka Yönetimi } \\
\text { - Marka Yönetimi } \\
\text { - Mesleki Beceri Kazandırma } \\
\text { - Mesleki Çalışma ve Seminer I } \\
\text { - Mesleki Çalışma ve Seminer II } \\
\text { - Mikro Ekonomi } \\
\text { - Mikro İktisat } \\
\text { - Muhasebe Denetimi }\end{array}$ & $\begin{array}{l}\text { - Türkiye Ekonomisi } \\
\text { - Uluslararası İşletmecilik } \\
\text { - Uluslararası Pazarlama } \\
\text { - Uygulamalı Girişimcilik } \\
\text { - Uygulamalı İstatistik } \\
\text { - Üniversite Külttürü } \\
\text { - Üretim Sistemleri } \\
\text { - Üretim Yönetimi } \\
\text { - Vergi Hukukuna Giriş } \\
\text { - Yenilik Yönetimi } \\
\text { - Yönetim Bilgi Sistemleri } \\
\text { - Yönetim Bilişim Sistemleri } \\
\text { - Yönetim Muhasebesi } \\
\text { - Yönetim Organizasyon } \\
\text { - Yönetim Organizasyon II } \\
\text { - Yönetim ve Organizasyon } \\
\text { - Yönetim ve Organizasyon I } \\
\text { - Yönetimde Güncel Yaklaşımlar } \\
\text { - Yönlendirilmiş Çalışma } \\
\text { - Yönlendirilmiş Çalı̧ma I } \\
\text { - Yönlendirilmiş Çalışma II }\end{array}$ \\
\hline
\end{tabular}

\subsection{Araştırmanın Yöntemi}

Verilerin analizinde tanımlayıcı istatistik yöntemleri kullanılmıştır. Meslek yüksekokullarının İşletme Yönetimi Bölümleri ders programlarından toplanan veriler öncelikle Microsoft Excel yardımıyla dönemler baz alınarak sınıflandırılmış ve analize uygun hale getirilmiştir. Daha sonra elde edilen verilerin frekans dağılımı belirlenmiştir. Araştırma grubundan elde edilen verilerin frekans dağılımı Stata 14.1 yardımı ile analiz edilmiştir. Derslerin sınıflandırması yapılırken dönemlerdeki verilme sıklığı dikkate alınmıştır. Verilen diğer dersler, ana dersler ile kıyaslandığında sayısal olarak çok az olması nedeniyle bir grupta toplanmıştır.

Araştırma kapsamında analize dahil edilen tüm meslek yüksekokullarının işletme yönetimi bölümlerinde eğitimi verilen derslere ait sınıflandırma ise, aşağıda tablolar halinde sunulmuştur.

Tablo 4. Birinci Dönem Derslerinin Sınıflandırılması

\begin{tabular}{|c|c|c|c|}
\hline İşletme I & Muhasebe ve Finans I & İktisat I & Hukuk I \\
\hline $\begin{array}{l}\text { - Genel İşletme } \\
\text { - Genel İşletme I } \\
\text { - Genel İşletmecilik Bilgisi } \\
\text { - İşletme } \\
\text { - İşletme Bilimine Giriş } \\
\text { - İşl. Çevresinde Güncel Yak. } \\
\text { - İşletme I } \\
\text { - İşletme Yönetimi I } \\
\text { - İşletmeciliğe Giriş } \\
\text { - İşletmeye Giriş }\end{array}$ & $\begin{array}{l}\text { - Genel Muhasebe } \\
\text { - Genel Muhasebe I } \\
\text { - Finansal Muhasebe } \\
\text { - Finansal Muhasebe I } \\
\text { - Muhasebe I } \\
\text { - Muhasebeye Giriş } \\
\text { - Finansin Temelleri }\end{array}$ & $\begin{array}{l}\text { - İktisada Giriş } \\
\text { - İktisada Giriş I } \\
\text { - İktisat I } \\
\text { - Genel Ekonomi } \\
\text { - Ekonomi } \\
\text { - Ekonomi I } \\
\text { - Mikro Ekonomi } \\
\text { - Mikro İktisat }\end{array}$ & $\begin{array}{l}\text { - Genel Hukuk } \\
\text { - Genel Hukuk Bilgisi } \\
\text { - Hukuk Bilgisi } \\
\text { - Hukuka Giriş } \\
\text { - Hukukun Temel Kavramları } \\
\text { - Temel Hukuk } \\
\text { - Temel Hukuk Bilgisi }\end{array}$ \\
\hline \multicolumn{4}{|c|}{ Verilen Diğer Dersler I } \\
\hline $\begin{array}{l}\text { - Araştırma Yöntemleri } \\
\text { - Bilgi ve İletişim Tekn. } \\
\text { - Bilgi ve İletişim Tekn. I } \\
\text { - Büro Yönetimi ve İletişim } \\
\text { - Büro Yönetimi ve İletişim Teknikleri } \\
\text { - Davranış Bilimleri } \\
\text { - E-Ticaret }\end{array}$ & $\begin{array}{l}\text { - Etik } \\
\text { - Girişimcilik I } \\
\text { - Halkla İlişkiler ve İletişim } \\
\text { - İletişim } \\
\text { - İletişime Giriş } \\
\text { - İstatistik } \\
\text { - İş Etiği }\end{array}$ & $\begin{array}{l}\text { - İş Sağlı̆̆ ve Güvenliği } \\
\text { - Kamu Yönetimi } \\
\text { - Kariyer Planlama } \\
\text { - Kariyer ve Yaşam Dersi } \\
\text { - Müşteri İlişkileri Yönetimi } \\
\text { - Örgütlerde Davranış } \\
\text { - Örgütsel Davranış } \\
\text { - Pazarlama }\end{array}$ & $\begin{array}{l}\text { - Pazarlama İlkeleri } \\
\text { - Pazarlama Yönetimi } \\
\text { - Sözleşme Yönetimi } \\
\text { - Temel Pazarlama } \\
\text { - Ticari Belgeler } \\
\text { - Üniversite Kültürü } \\
\text { - Yönetim ve Organizasyon } \\
\text { - Yönlendirilmiș Çalıșma I }\end{array}$ \\
\hline
\end{tabular}

Birinci dönemde okutulan derslerin büyük çoğunluğu genel muhasebe, genel işletme, iktisat ve hukuk derslerinden oluşturmaktadır. Birçok ders aynı içerikle fakat farklı isimlerle verilmektedir (Örneğin; Genel İşletme I, İşletme Yönetimi I, İşletmeciliğe Giriş ve İşletmeye Giriş). Bu nedenle birinci dönem derslerinin sınıflandırılması temel alan ve ders içerikleri dikkate alınarak yapılmıştır. Bu bağlamda benzer içerikli ve benzer isimli dersler; İşletme I, Muhasebe ve Finans I, İktisat I, Hukuk I çatısı altında toplanarak sınıflandırılmıştır. Farklı fakat derslerin verilme sıklığı çok az olanlar ise Verilen Diğer Dersler I ismi altında kategorize edilmiştir. 
Tablo 5. İkinci Dönem Derslerinin Sınıflandırılması

\begin{tabular}{|c|c|c|c|}
\hline İșletme II & Muhasebe ve Finans II & İktisat II & Hukuk II \\
\hline $\begin{array}{l}\text { - Genel İşletme } \\
\text { • Genel İşletme II } \\
\text { • İşletme II } \\
\text { - İşletme Yöneticiliği } \\
\text { • İşletme Yönetimi } \\
\text { • İşletme Yönetimi II } \\
\end{array}$ & \multirow{3}{*}{$\begin{array}{l}\text { - Genel Muhasebe II } \\
\text { - Genel Muhasebe II } \\
\text { - Dönem Sonu Muhasebe } \\
\text { İşlemleri } \\
\text { - Finansal Muhasebe II } \\
\text { - Muhasebe II } \\
\text { - Muhasebe İlkeleri } \\
\text { - Muhasebe Uygulamaları ve } \\
\text { Ticari Belgeler } \\
\text { - Envanter İşlemleri ve } \\
\text { Bilanço }\end{array}$} & \multirow{3}{*}{$\begin{array}{l}\text { - Makro Ekonomi } \\
\text { - Makro İktisat } \\
\text { - İktisada Giriş II } \\
\text { - İktisat II } \\
\text { - Ekonomi II } \\
\text { - Mikro Ekonomi } \\
\text { - Mikro İktisat }\end{array}$} & \multirow{3}{*}{$\begin{array}{l}\text { - İş ve Sosyal Güvenlik } \\
\text { Hukuku } \\
\text { • Hukukun Temel Kavramları } \\
\text { - İşletme Hukuku } \\
\text { - Borçlar Hukuku } \\
\text { - Şirketler Muhasebesi } \\
\text { - Temel Hukuk } \\
\text { - Ticaret Hukuk Bilgisi } \\
\text { - Ticaret Hukuku } \\
\text { - Ticaret Hukuku Bilgisi }\end{array}$} \\
\hline İstatistik & & & \\
\hline - İstatistik & & & \\
\hline \multicolumn{4}{|c|}{ Verilen Diğer Dersler II } \\
\hline $\begin{array}{l}\text { - Araştırma Yöntem ve Teknikleri } \\
\text { - Araştırma Yöntemleri ve Seminer } \\
\text { - Bilgi ve İletişim Teknolojileri } \\
\text { - Bilgi ve İletişim Teknolojileri II } \\
\text { - Bilgisayar Büro Programları } \\
\text { - Büro Yönetimi ve İletiş̧im Teknikleri } \\
\text { - Davranış Bilimleri } \\
\text { - Dijital Okuryazarlık } \\
\text { - E-Ticaret } \\
\text { - Finans Matematiği } \\
\text { - Girişimcilik } \\
\text { - Girişimcilik ve Proje Yönetimi } \\
\text { - Halka İlişkiler Yönetimi } \\
\text { - Halkla İlişkiler } \\
\text { - Halkla İlişkiler ve İletişim } \\
\text { - İletişisim } \\
\text { - İșletme Becerileri Grup Çalışması }\end{array}$ & $\begin{array}{l}\text { - İșl. Kararlarının Alınması } \\
\text { - Işletme Stratejilerinde } \\
\text { Güncel Yaklaşımlar } \\
\text { - İşletmelerde Bilgisayar } \\
\text { Uygulamaları } \\
\text { - İşletmelerde Etik } \\
\text { - İşletmelerde Problem Çözme } \\
\text { ve Karar verme Süreçleri } \\
\text { - Kalite Güvencesi ve Kalite } \\
\text { Yönetim Sistemleri } \\
\text { - Kalite Yönetim Sistemleri } \\
\text { - Kalite Yönetimi } \\
\text { - Kamu Maliyesi } \\
\text { - Kariyer Planlaması } \\
\text { - Kariyer Yönetimi }\end{array}$ & $\begin{array}{l}\text { - Kongre ve Fuar Yönetimi } \\
\text { - Lojistik } \\
\text { - Müşteri İlişskileri Yönetimi } \\
\text { - Örgütsel Davranış } \\
\text { - Pazarlama } \\
\text { - Pazarlama İlkeleri } \\
\text { - Pazarlama Yönetimi } \\
\text { - İletişim ve Bilgi Yönetimi } \\
\text { - İletişim ve Etik } \\
\text { - İletişim ve Halkla İlişskiler } \\
\text { - İnsan Kaynakları } \\
\text { - İnsan Kaynakları Yönetimi } \\
\text { - İş Sağlığı ve Güvenliği }\end{array}$ & $\begin{array}{l}\text { - İș Sağlığı ve İş Güvenliği } \\
\text { - Iş Yeri Uygulaması } \\
\text { - İşletme Becerileri } \\
\text { • Proje Analizi ve } \\
\text { - Değerlendirme } \\
\text { - Sosyal Bilimlerde İstatistik } \\
\text { • Temel İletişim } \\
\text { - Ticari Belgeler } \\
\text { - Toplam Kalite Yönetimi } \\
\text { - Toplum Bilim } \\
\text { - Üretim Yönetim } \\
\text { • Üretim Yönetimi } \\
\text { - Yönetim Bilişim Sistemleri } \\
\text { - Yönetim Organizasyon } \\
\text { - Yönetim ve Organizasyon } \\
\text { - Yönlendirilmiş Çalışma II } \\
\end{array}$ \\
\hline
\end{tabular}

İkinci döneme ait derslerde yapılan sınıflandırma için birinci dönemde dikkate alınan esaslar aynı şekilde uygulanmıştır. Bu kapsamda okutulan tüm dersler, İşletme II, Muhasebe ve Finans II, İktisat II, Hukuk II, İstatistik ve Verilen Diğer Dersler II adıyla sınıflandırılmıştır. Bu dönemde de Verilen Diğer Dersler II sınıfındaki derslerin sayısının oldukça az olması sınıflandırma kriteri olarak dikkate alınmıştır.

Tablo 6. Üçüncü Dönem Derslerinin Sınıflandırılması

\begin{tabular}{|c|c|c|c|}
\hline Örgütsel Davranış & İnsan Kaynakları & Üretim Yönetimi & Halkla İlișkiler \\
\hline $\begin{array}{l}\text { • Örgütsel Davranış } \\
\text { • Örgüt Teorisi }\end{array}$ & - İnsan Kaynakları & $\begin{array}{l}\text { - Üretim Yönetimi } \\
\text { - Üretim Sistemleri } \\
\text { - Lojistik Yönetimi }\end{array}$ & • Halkla İlişkiler \\
\hline \multicolumn{4}{|c|}{ Dış Ticaret İşlemleri } \\
\hline - Dış Tícaret İşlemleri & \multicolumn{3}{|c|}{ - Dış Ticaret İşlemleri Yönetimi } \\
\hline \multicolumn{4}{|c|}{ Yönetim Organizasyon } \\
\hline $\begin{array}{l}\text { • Güncel Yönetim } \\
\text { Teknikleri }\end{array}$ & $\begin{array}{l}\text { - Liderlik ve Yönetişim } \\
\text { - İşletme Yönetimi }\end{array}$ & - Stratejik Yönetim & $\begin{array}{l}\text { • Yönetim Organizasyon } \\
\text { • Yönetim ve Organizasyon }\end{array}$ \\
\hline \multicolumn{4}{|c|}{ Pazarlama } \\
\hline $\begin{array}{l}\text { - Pazarlama } \\
\text { - Pazarlama Illkeleri } \\
\text { - Tüketici Davranışları }\end{array}$ & $\begin{array}{l}\text { - Pazarlama ve Satış } \\
\text { Teknikleri } \\
\text { - E-Ticaret }\end{array}$ & $\begin{array}{l}\text { - Pazarlama Yönetimi } \\
\text { - Pazarlama Yönetimi I } \\
\text { - Satış Yönetimi }\end{array}$ & $\begin{array}{l}\text { - Pazarlamaya Giriş } \\
\text { - Müşteri İlişkileri Yönetimi }\end{array}$ \\
\hline \multicolumn{4}{|c|}{ Hukuk III } \\
\hline $\begin{array}{l}\text { • İş ve Sosyal Güvenlik } \\
\text { Hukuku }\end{array}$ & $\begin{array}{l}\text { - Vergi Hukukuna Giriş̧ } \\
\text { - Borçlar Hukuku Bilgisi }\end{array}$ & $\begin{array}{l}\text { - Ticaret Hukuku } \\
\bullet \text { Vergi Hukuku }\end{array}$ & $\begin{array}{l}\text { - Hukuka Giriş ve Savunma } \\
\text { Mevzuatı } \\
\text { - Kıymetli Evrak Hukuku }\end{array}$ \\
\hline \multicolumn{4}{|c|}{ Muhasebe ve Finans III } \\
\hline $\begin{array}{l}\text { - Bilgisayarlı Muhasebe } \\
\text { - Bilgisayarlı Muhasebe I } \\
\text { - Mali Tablolar Analizi } \\
\text { - Maliyet Analizi }\end{array}$ & $\begin{array}{l}\text { - Muhasebe Denetimi } \\
\text { - Muhasebe İşlemleri } \\
\text { - Muhasebe Paket Programları } \\
\text { - Maliyet Muhasebesi }\end{array}$ & $\begin{array}{l}\text { - Yönetim Muhasebesi } \\
\text { - Şirketler Muhasebesi } \\
\text { - Finansal Piyasalar ve } \\
\text { Yatırım Araçları }\end{array}$ & $\begin{array}{l}\text { - Finansal Yönetim } \\
\text { - Para ve Sermaye Piyasaları } \\
\text { - İşletme Finansmanı } \\
\text { - Sermaye Piyasası }\end{array}$ \\
\hline \multicolumn{4}{|c|}{ Verilen Diğer Dersler III } \\
\hline $\begin{array}{l}\text { - Araştırma Yöntemleri ve } \\
\text { Teknikleri } \\
\text { - Ar-Ge ve Yenilik } \\
\text { - Yönlendirilmiş Çalısşma } \\
\text { - Yönlendirilmiş Çalı̧ma I } \\
\text { - Girişimcilik }\end{array}$ & $\begin{array}{l}\text { - Proje Yönetimi } \\
\text { - Risk Yönetimi } \\
\text { - Yenilik Yönetimi } \\
\text { - Makro İktisat } \\
\text { - Proje Yönetimi ve } \\
\quad \text { Uygulamaları }\end{array}$ & $\begin{array}{l}\text { - İletişim ve Etik } \\
\text { - Ticari Belgeler } \\
\text { - Ticari Belgeler ve } \\
\text { Uygulama } \\
\text { - Toplam Kalite Yönetimi }\end{array}$ & $\begin{array}{l}\text { - Girişimcilik ve Küçük İşletme } \\
\text { Yöneticiliği } \\
\text { - Kamu Maliyesi } \\
\text { - Kişisel ve Profesyonel Gelişim } \\
\text { - Mesleki Çalışma ve Seminer I } \\
\text { - İstatistik }\end{array}$ \\
\hline
\end{tabular}




\begin{tabular}{|llll|} 
• Girişimcilik I & $\bullet$ Temel Ekonomi & $\bullet$ İşletmecilik Uygulamaları & $\bullet$ İstatistik I \\
$\bullet$ Girişimcilik ve İşletme & $\bullet$ Türkiye Ekonomisi & I & $\bullet$ Para Banka \\
Yöneticiliği I & $\bullet$ Ekonomi II & $\bullet$ Kalite Güvence ve & $\bullet$ Para ve Banka \\
• Proje Yönetimi & $\bullet$ Uluslararası İșletmecilik & Standartları & $\bullet$ Türk vergi Sistemi \\
& $\bullet$ Uygulamalı İstatistik & $\bullet$ Kalite Yönetim & \\
& $\bullet$ İletişsim & $\bullet$ Kalite Yönetim Sistemleri & \\
\hline
\end{tabular}

Üçüncü ve dördüncü dönemlerde derslere ilişkin çeşitlilik artmakla beraber sınıflandırma kriterleri aynı ilk iki dönemde olduğu gibi yapılmıştır. Sınıflandırmaya ilişkin detaylar yukarıdaki Tablo 6. ve aşağıdaki Tablo 7'de gösterilmektedir.

Tablo 7. Dördüncü Dönem Derslerinin Sinıflandırılması

\begin{tabular}{|c|c|c|c|}
\hline \multicolumn{4}{|c|}{ Muhasebe ve Finans IV } \\
\hline $\begin{array}{l}\text { - Finansal Analiz } \\
\text { - Finansal Yatırım Araçları } \\
\text { - Finansal Yönetim } \\
\text { - Banka Muhasebesi }\end{array}$ & $\begin{array}{l}\text { - Bilgisayarlı Muhasebe } \\
\text { - Bilgisayarlı Muhasebe II } \\
\text { - Bilgisayarlı Muhasebe } \\
\text { Uygulamaları } \\
\text { - Envanter Bilanço }\end{array}$ & $\begin{array}{l}\text { - Mali Tablolar Analizi } \\
\text { - Maliyet Muhasebesi } \\
\text { - Yönetim Muhasebesi } \\
\text { - D1ş Ticaret İşlemleri } \\
\text { Muhasebesi }\end{array}$ & $\begin{array}{l}\text { - Sermaye Piyasası İşlemleri } \\
\text { - Şirketler Muhasebesi } \\
\text { - Muhasebe Standartları } \\
\text { - Finansal Okuryazarlık }\end{array}$ \\
\hline Örgütsel Davranış & İnsan Kaynakları Yönetimi & Üretim Yönetimi & Hukuk IV \\
\hline • Örgütsel Davranış & $\begin{array}{l}\text { - İnsan Kaynakları Yönetimi } \\
\text { • İşe Alım ve Mülakat } \\
\text { Teknikleri }\end{array}$ & $\begin{array}{l}\text { • Üretim Yönetimi } \\
\bullet \text { Lojistik } \\
\bullet \text { Lojistik Yönetimi } \\
\text { • Tedarik Zinciri Yönetimi }\end{array}$ & $\begin{array}{l}\text { - İş ve Sosyal Güvenlik Hukuku } \\
\text { - Anayasa Hukuku } \\
\text { - Borçlar Hukuku } \\
\text { - Ticaret Hukuku }\end{array}$ \\
\hline \multicolumn{4}{|c|}{ Yönetim Organizasyon } \\
\hline • Yönetim Organizasyon & $\begin{array}{l}\text { - Yönetim ve Organizasyon II } \\
\text { - Stratejik Yönetim }\end{array}$ & $\begin{array}{l}\text { - İşletme Stratejileri } \\
\text { - Çağdaş Yönetim Yaklaşımları }\end{array}$ & $\begin{array}{l}\text { - Yönetimde Güncel Yaklaşımlar } \\
\text { - Yönetim ve Organizasyon }\end{array}$ \\
\hline \multicolumn{4}{|c|}{ Girişimcilik } \\
\hline $\begin{array}{l}\text { • Girişimcilik } \\
\text { • Girişimcilik II }\end{array}$ & $\begin{array}{l}\text { • Girişimcilik ve Küçük İşletme } \\
\text { Yöneticiliği/Yönetimi }\end{array}$ & • Girişimcilik ve Örgüt Kültürü & $\begin{array}{l}\text { - Uygulamalı Girişimcilik } \\
\text { - Teknoloji İnovasyon ve } \\
\text { Girişimcilik }\end{array}$ \\
\hline \multicolumn{3}{|c|}{ Verilen Diğer Dersler IV } & Pazarlama \\
\hline $\begin{array}{l}\text { - Araştırma Projesi } \\
\text { - Araştırma Yöntemleri } \\
\text { - Avrupa Birliği ve } \\
\text { İşletmecilik } \\
\text { - Bilimsel Araştırma } \\
\text { Yöntem ve Teknikleri } \\
\text { - Demokrasi ve Sivil } \\
\text { Toplum } \\
\text { - İnovasyon ve Proje } \\
\text { Yönetimi } \\
\text { - İstatistik } \\
\text { - İstatistik II }\end{array}$ & $\begin{array}{l}\text { - İş Yeri Uygulaması } \\
\text { - İşletme Yönetimi } \\
\text { Yönlendirilmiş Çalışma } \\
\text { - İşletmecilik Uygulamaları II } \\
\text { - Isşyeri Eğitimi } \\
\text { - İşyeri Eğitimi Uygulamaları } \\
\text { - Kamu Maliyesi } \\
\text { - Kriz Yönetimi } \\
\text { - Kurumsal Yönetim } \\
\text { - Mesleki Beceri Kazandırma } \\
\text { - Proje Yönetimi II } \\
\text { - Mesleki Çalışma ve Seminer II }\end{array}$ & $\begin{array}{l}\text { - İş Etiği } \\
\text { • İs Sağlığı ve Güvenliği Sosyal } \\
\text { Bilimlerde Araştırma } \\
\text { Yöntemleri } \\
\text { • Sosyolojiye Giriş } \\
\text { • Ticari Belgeler } \\
\text { • Toplam Kalite Yönetimi } \\
\text { • Yönetim Bilgi Sistemleri } \\
\text { • Yönlendirilmiş Çalışma } \\
\text { • Yönlendirilmiş Çalışma II } \\
\text { • İstatistik Paket Programları } \\
\text { - Türk Vergi Sistemi }\end{array}$ & $\begin{array}{l}\text { - Pazar Araştırması } \\
\text { - Pazarlama } \\
\text { - Pazarlama Araştırması } \\
\text { - Pazarlama ve Satış Yönetimi } \\
\text { - Pazarlama Yönetimi } \\
\text { - Pazarlama Yönetimi II } \\
\text { - Uluslararası Pazarlama } \\
\text { - Marka ve Marka Yönetimi } \\
\text { - Marka Yönetimi } \\
\text { - Müşteri İlişkileri Yönetimi } \\
\text { - Satış ve Pazarlama Teknikleri } \\
\text { - E-Ticaret } \\
\text { - Tüketici Davranışları } \\
\text { - Satış Yönetimi } \\
\end{array}$ \\
\hline
\end{tabular}

Son olarak genel değerlendirmede kullanılmak üzere, işletme yönetimi bölümü eğitimi boyunca (yani dört dönemde) okutulan dersler tekrar bir sınıflandırmaya tabi tutulmuştur. Bunun nedeni aynı veya benzer derslerin farklı dönemlerde de verilmesi ve sayısal olarak az olan derslerin diğer dersler sınıflandırmasına girmesidir. Bu derslere ilişkin genel değerleri ortaya koymak adına dört dönem baz alınarak ders sınıflandırılmasına gidilmiştir. Yapılan son sınıflandırmaya ilişkin açıklamalar Tablo 8'de gösterilmektedir.

Tablo 8. Genel Değerlendirme için Tüm Derslerin Sınıflandırılması

\begin{tabular}{|c|c|c|c|}
\hline \multicolumn{4}{|c|}{ GENEL ISSLETME } \\
\hline $\begin{array}{l}\text { - Genel İşletme } \\
\text { - Genel İşletme I } \\
\text { - Genel İşletme II } \\
\text { - Genel İşletmecilik Bilgisi } \\
\text { - İşletme }\end{array}$ & $\begin{array}{l}\text { - İşletme Bilimine Giriş } \\
\text { - İşletme Çevresinde Güncel } \\
\text { Yaklaşımlar } \\
\text { - İşletme I } \\
\text { - İşletme II } \\
\end{array}$ & $\begin{array}{l}\text { - İşletme Yöneticiliği } \\
\text { - Işletme Yönetimi } \\
\text { - Isşletme Yönetimi I } \\
\text { - İşletme Yönetimi II } \\
\text { - }\end{array}$ & $\begin{array}{l}\text { - İşletmecilik Uygulamaları I } \\
\text { - İşletmeciliğe Giriş } \\
\text { - İşletmelerde Bilgi Teknolojileri } \\
\text { Kullanımı I } \\
\text { - İşletmeye Giriş }\end{array}$ \\
\hline \multicolumn{4}{|c|}{$\begin{array}{l}\text { YÖNETIM ORGANIZASYON } \\
\end{array}$} \\
\hline $\begin{array}{l}\text { - Çağdaş Yönetim Yaklaşımları } \\
\text { • Güncel Yönetim Teknikleri } \\
\text { • İşletme Stratejileri }\end{array}$ & $\begin{array}{l}\text { - İşletme Stratejilerinde Güncel } \\
\text { Yaklaşımlar } \\
\text { - İşletme Yönetimi } \\
\text { - Liderlik ve Yönetişim }\end{array}$ & $\begin{array}{l}\text { - Stratejik Yönetim } \\
\text { - Yönetim Bilişim Sistemleri } \\
\text { - Yönetim Organizasyon } \\
\text { - Yönetim Organizasyon II }\end{array}$ & $\begin{array}{l}\text { - Yönetim ve Organizasyon } \\
\text { • Yönetim ve Organizasyon I } \\
\text { • Yönetimde Güncel Yaklaşımlar }\end{array}$ \\
\hline \multicolumn{4}{|c|}{ İKTÍSAT } \\
\hline $\begin{array}{l}\text { - Ekonomi } \\
\text { - Ekonomi I } \\
\text { - Ekonomi II }\end{array}$ & $\begin{array}{l}\text { - İktisada Giriş } \\
\text { - İktisada Giriş I } \\
\text { - İktisada Giriş II }\end{array}$ & $\begin{array}{l}\text { - İktisat II } \\
\text { - Makro Ekonomi } \\
\text { - Makro İktisat }\end{array}$ & $\begin{array}{l}\text { - Mikro İktisat } \\
\text { - Para Banka } \\
\text { - Para ve Banka }\end{array}$ \\
\hline
\end{tabular}




\begin{tabular}{|c|c|c|c|}
\hline • Genel Ekonomi & - İktisat I & $\bullet$ Ekonomi & $\begin{array}{l}\text { - Temel Ekonomi } \\
\text { - Türkiye Ekonomisi }\end{array}$ \\
\hline \multicolumn{4}{|c|}{ PAZARLAMA } \\
\hline $\begin{array}{l}\text { - E-Ticaret } \\
\text { - Marka ve Marka Yönetimi } \\
\text { - Marka Yönetimi } \\
\text { - Müşteri İlişkileri Yönetimi } \\
\text { - Pazar Araștırması }\end{array}$ & $\begin{array}{l}\text { - Pazarlama } \\
\text { - Pazarlama Araştırması } \\
\text { - Pazarlama İlkeleri } \\
\text { - Pazarlama ve Satış Teknikleri } \\
\text { - Pazarlama ve Satıș Yönetimi }\end{array}$ & $\begin{array}{l}\text { - Pazarlama Yönetimi } \\
\text { - Pazarlama Yönetimi I } \\
\text { - Pazarlama Yönetimi II } \\
\text { - Pazarlamaya Giriş }\end{array}$ & $\begin{array}{l}\text { - Satış ve Pazarlama Teknikleri } \\
\text { - Satış Yönetimi } \\
\text { - Temel Pazarlama } \\
\text { - Tüketici Davranışları } \\
\text { - Uluslararası Pazarlama }\end{array}$ \\
\hline \multicolumn{4}{|c|}{ HUKUK } \\
\hline $\begin{array}{l}\text { - Anayasa Hukuku } \\
\text { - Borçlar Hukuku } \\
\text { - Borçlar Hukuku Bilgisi } \\
\text { - Genel Hukuk } \\
\text { - Genel Hukuk Bilgisi } \\
\text { - Hukuk Bilgisi }\end{array}$ & $\begin{array}{l}\text { - Hukuka Giriş } \\
\text { - Hukuka Giriş ve Savunma } \\
\text { Mevzuatı } \\
\text { - Hukukun Temel Kavramları } \\
\text { - İş ve Sosyal Güvenlik Hukuku }\end{array}$ & $\begin{array}{l}\text { - İşletme Hukuku } \\
\text { - Kiymetli Evrak Hukuku } \\
\text { - Şirketler Muhasebesi } \\
\text { - Temel Hukuk } \\
\text { - Temel Hukuk Bilgisi }\end{array}$ & $\begin{array}{l}\text { - Ticaret Hukuk Bilgisi } \\
\text { - Ticaret Hukuku } \\
\text { - Ticaret Hukuku Bilgisi } \\
\text { - Vergi Hukuku } \\
\text { - Vergi Hukukuna Giriş }\end{array}$ \\
\hline \multicolumn{4}{|c|}{ HALKA İLİŞKİLER } \\
\hline $\begin{array}{l}\text { - Halka İlişkiler ve İletişim } \\
\text { • Halka İlişkiler Yönetimi }\end{array}$ & $\begin{array}{l}\text { - Halkla İlişkiler } \\
\text { - Halkla İlişkiler ve İletişim }\end{array}$ & - Halka İlişkiler & • İletişim ve Halkla İlişkiler \\
\hline \multicolumn{4}{|c|}{ GÍRİ̧ìiMCİLIK } \\
\hline $\begin{array}{l}\text { • Girişimcilik ve İşletme } \\
\text { Yöneticiliği I } \\
\text { • Girişimcilik } \\
\text { • Girişimcilik I }\end{array}$ & $\begin{array}{l}\text { - Girişimcilik II } \\
\text { - Girişimcilik ve Küçük İşletme } \\
\text { Yöneticiliği } \\
\text { - Girişimcilik ve Küçük İşletme } \\
\text { Yönetimi }\end{array}$ & $\begin{array}{l}\text { - Girişimcilik ve Örgüt } \\
\text { Kültürü } \\
\text { • Girişimcilik ve Proje } \\
\text { Yönetimi }\end{array}$ & $\begin{array}{l}\text { - Teknoloji İnovasyon ve } \\
\text { Girişimcilik } \\
\text { - Uygulamalı Girişimcilik }\end{array}$ \\
\hline \multicolumn{4}{|c|}{ İSTATÍSTIK } \\
\hline $\begin{array}{l}\text { - İstatistik } \\
\text { - Uygulamalı İstatistik }\end{array}$ & $\begin{array}{l}\text { - İstatistik I } \\
\text { - İstatistik II }\end{array}$ & - İstatistik Paket Programları & - Sosyal Bilimlerde İstatistik \\
\hline \multicolumn{4}{|c|}{ DIŞ TİCARET İŞLEMLERİ } \\
\hline & • Diș Ticaret İșlemleri & • Diş Ticaret İşlemleri Yönetimi & \\
\hline \multicolumn{4}{|c|}{ İNSAN KAYNAKLARI } \\
\hline $\begin{array}{l}\text { - İnsan Kaynakları } \\
\text { - İnsan Kaynakları Yön. }\end{array}$ & $\begin{array}{l}\text { - İşe Alım ve Mülakat } \\
\text { Teknikleri }\end{array}$ & $\begin{array}{l}\text { - Kariyer Planlama } \\
\text { - Kariyer Planlaması }\end{array}$ & $\begin{array}{l}\text { - Kariyer ve Yaşam } \\
\text { - Kariyer Yönetimi }\end{array}$ \\
\hline \multicolumn{4}{|c|}{ ÖRGÜTSEL DAVRANIŞ } \\
\hline • Örgütlerde Davranış & • Örgütsel Davranış & - Örgüt Teorisi & \\
\hline \multicolumn{4}{|c|}{ ÜRETİM YÖNETİMI } \\
\hline $\begin{array}{l}\text { - Lojistik } \\
\text { - Üretim Yönetimi }\end{array}$ & $\begin{array}{l}\text { - Üretim Sistemleri } \\
\text { - Lojistik Yönetimi }\end{array}$ & - Tedarik Zinciri Yönetimi & \\
\hline \multicolumn{4}{|c|}{ MUHASEBE VE FINANS } \\
\hline $\begin{array}{l}\text { - Banka Muhasebesi } \\
\text { - Bilgisayarlı Muhasebe } \\
\text { - Bilgisayarlı Muhasebe I } \\
\text { - Bilgisayarlı Muhasebe II } \\
\text { - Bilgisayarlı Muhasebe } \\
\text { Uygulamaları } \\
\text { - Diş Ticaret İşlemleri } \\
\text { Muhasebesi } \\
\text { - Dönem Sonu Muhasebe } \\
\text { İşlemleri } \\
\text { - Envanter Bilanço }\end{array}$ & $\begin{array}{l}\text { - Envanter İşlemleri ve Bilanço } \\
\text { - Finans Matematiği } \\
\text { - Finansal Analiz } \\
\text { - Finansal Muhasebe } \\
\text { - Finansal Muhasebe I } \\
\text { - Finansal Muhasebe II } \\
\text { - Finansal Okuryazarlık } \\
\text { - Finansal Piyasalar ve Yatırım } \\
\text { Araçları } \\
\text { - Finansal Yatırım Araçları } \\
\text { - Finansal Yönetim }\end{array}$ & $\begin{array}{l}\text { - Finansin Temelleri } \\
\text { - Genel Muhasebe } \\
\text { - Genel Muhasebe I } \\
\text { - Genel Muhasebe II } \\
\text { - İşletme Finansmanı } \\
\text { - Mali Tablolar Analizi } \\
\text { - Maliyet Analizi } \\
\text { - Maliyet Muhasebesi } \\
\text { - Muhasebe Denetimi } \\
\text { - Muhasebe I } \\
\text { - Muhasebe II } \\
\text { - Muhasebe İlkeleri }\end{array}$ & $\begin{array}{l}\text { - Muhasebe İşlemleri } \\
\text { - Muhasebe Paket Programları } \\
\text { - Muhasebe Standartları } \\
\text { - Muhasebe Uygulamaları ve } \\
\text { Ticari Belgeler } \\
\text { - Muhasebeye Giriş } \\
\text { - Para ve Sermaye Piyasaları } \\
\text { - Sermaye Piyasası } \\
\text { - Sermaye Piyasası İşlemleri } \\
\text { - Şirketler Muhasebesi } \\
\text { - Yönetim Muhasebesi }\end{array}$ \\
\hline \multicolumn{4}{|c|}{ VERİLEN DİĞER DERSLER } \\
\hline $\begin{array}{l}\text { - Araştırma Projesi } \\
\text { - Araştırma Yöntem ve } \\
\text { Teknikleri } \\
\text { - Araştırma Yöntemleri } \\
\text { - Araştırma Yöntemleri ve } \\
\text { Seminer } \\
\text { - Araştırma Yöntemleri ve } \\
\text { Teknikleri } \\
\text { - Ar-Ge ve Yenilik } \\
\text { - Avrupa Birliği ve İşletmecilik } \\
\text { - Bilgi ve İletişim Teknolojileri } \\
\text { - Bilgi ve İletişim Teknolojileri I } \\
\text { - Bilgi ve İletişim Teknolojileri } \\
\text { II } \\
\text { - Bilgi ve İletişisim Teknolojisi I } \\
\text { - Bilgisayar Büro Programları }\end{array}$ & $\begin{array}{l}\text { - Davranış Bilimleri } \\
\text { - Demokrasi ve Sivil Toplum } \\
\text { - Dijital Okuryazarlık } \\
\text { - Etik } \\
\text { - İletişim } \\
\text { - İletişim ve Bilgi Yönetimi } \\
\text { - İletişim ve Etik } \\
\text { - İletişime Giriş } \\
\text { - İnovasyon ve Proje Yönetimi } \\
\text { - İş Etiği } \\
\text { - İs Sağlığı ve Güvenliği } \\
\text { - İs Sağlığı ve İş Güvenliği } \\
\text { - İs Yeri Uygulaması } \\
\text { - İşletme Becerileri } \\
\text { - İşletme Becerileri Grup } \\
\text { Çalışması } \\
\text { - İşletme Kararlarının Alınması }\end{array}$ & $\begin{array}{l}\text { - İşletmelerde Problem Çözme } \\
\text { ve Karar verme } \\
\text { - Süreçleri } \\
\text { - İşyeri Eğitimi } \\
\text { - İşyeri Eğitimi } \\
\text { - İşyeri Eğitimi Uygulamaları } \\
\text { - Kalite Güvence ve Standartları } \\
\text { - Kalite Güvencesi ve Kalite } \\
\text { Yönetim Sistemleri } \\
\text { - Kalite Yönetim } \\
\text { - Kalite Yönetim Sistemleri } \\
\text { - Kalite Yönetimi } \\
\text { - Kamu Maliyesi } \\
\text { - Kamu Yönetimi } \\
\text { - Kişisel ve Profesyonel Gelişim } \\
\text { - Kongre ve Fuar Yönetimi } \\
\text { - Kriz Yönetimi }\end{array}$ & $\begin{array}{l}\text { - Proje Analizi ve } \\
\text { Değerlendirme } \\
\text { - Proje Yönetimi } \\
\text { - Proje Yönetimi I } \\
\text { - Proje Yönetimi II } \\
\text { - Proje Yönetimi ve } \\
\text { Uygulamaları } \\
\text { - Risk Yönetimi } \\
\text { - Sosyal Bilimlerde Araştırma } \\
\text { Yöntemleri } \\
\text { - Sosyolojiye Giriş } \\
\text { - Sözleşme Yönetimi } \\
\text { - Temel İletişim } \\
\text { - Ticari Belgeler } \\
\text { - Ticari Belgeler ve Uygulama } \\
\text { - Toplam Kalite Yönetimi } \\
\text { - Toplum Bilim }\end{array}$ \\
\hline
\end{tabular}




\begin{tabular}{|c|c|c|c|}
\hline $\begin{array}{l}\text { - Bilimsel Araştırma Yöntem ve } \\
\text { Teknikleri } \\
\text { - Büro Yönetimi ve İletişim } \\
\text { - Büro Yönetimi ve İletişim } \\
\text { Teknikler } \\
\text { - Büro Yönetimi ve İletişim } \\
\text { Teknikleri }\end{array}$ & $\begin{array}{l}\text { - İşletme Yönetimi } \\
\text { Yönlendirilmiş Çalışma } \\
\text { - İşletmecilik Uygulamaları II } \\
\text { - İşletmelerde Bilgisayar } \\
\text { Uygulamaları } \\
\text { - İşletmelerde Etik }\end{array}$ & $\begin{array}{l}\text { - Kurumsal Yönetim } \\
\text { - Mesleki Beceri Kazandırma } \\
\text { - Mesleki Çalışma ve Seminer I } \\
\text { - Mesleki Çalışma ve Seminer II }\end{array}$ & $\begin{array}{l}\text { - Türk vergi Sistemi } \\
\text { - Uluslararası İşletmecilik } \\
\text { - Üniversite Kültürü } \\
\text { - Yenilik Yönetimi } \\
\text { - Yönetim Bilgi Sistemleri } \\
\text { - Yönlendirilmiş Çalışma } \\
\text { - Yönlendirilmiş Çalışma I } \\
\text { - Yönlendirilmiş Çalışma II }\end{array}$ \\
\hline
\end{tabular}

Derslerin sınıflandırılması dönem bazlı olarak Tablo 4, 5, 6 ve 7'de ve tüm dönemlerin dikkate alınmasıyla oluşturulmuş sınıflandırılma ise Tablo 8.'de detaylı bir şekilde sunulmuştur. Sayısal verilere ilişkin bulgular bir sonraki bölümde değerlendirilerek yorumlanacaktır.

\subsection{Araştırmanın Bulguları ve Sonuçlarının Değerlendirilmesi}

İşletme Yönetimi Bölümlerinde verilen derslerin (Tablo 4, 5, 6, 7 ve 8'deki sınıflandırmaya bağlı kalınarak) dönemsel olarak sayıları, ders saatlerinin ortalamaları ve yüzdeleri saptanmıştır. Dört dönem boyunca eğitim veren işletme yönetimi bölümüne ait dönemsel ders dağılımları, aşağıdaki tablolarda sırasıyla gösterilmiştir.

Tablo 9. Birinci Dönem Ders ve Haftalık Ders Saatlerinin Dağılımı

\begin{tabular}{|c|c|c|c|c|c|c|c|}
\hline \multirow{2}{*}{$\begin{array}{c}\text { Sinıflandırılan } \\
\text { Dersler }\end{array}$} & \multirow{2}{*}{$\begin{array}{r}\text { Ders } \\
\text { Sayısı }\end{array}$} & \multicolumn{4}{|c|}{ Ders Saati } & \multirow{2}{*}{$\begin{array}{c}\text { Ders } \\
\text { Sayısının } \\
\text { Genel } \\
\text { Toplam } \\
\text { Ăğırlığı } \\
\end{array}$} & \multirow{2}{*}{$\begin{array}{c}\text { Ders Saati } \\
\text { Toplamının } \\
\text { Genel Toplam } \\
\text { Ağırlığı }\end{array}$} \\
\hline & & Toplamı & $\operatorname{En} A z$ & En Fazla & Ortalaması & & \\
\hline İşletme I & 73 & 234 & 2 & 4 & 3,2 & $20,98 \%$ & $23,95 \%$ \\
\hline Muhasebe ve Finans I & 71 & 243 & 2 & 4 & 3,42 & $20,40 \%$ & $24,87 \%$ \\
\hline İktisat I & 70 & 186 & 2 & 4 & 2,65 & $20,11 \%$ & $19,04 \%$ \\
\hline Hukuk I & 66 & 153 & 2 & 4 & 2,31 & $18,97 \%$ & $15,66 \%$ \\
\hline Verilen Diğer Dersler I & 68 & 161 & 1 & 3 & 2,37 & $19,54 \%$ & $16,48 \%$ \\
\hline Genel Toplam & 348 & 977 & & & & & \\
\hline
\end{tabular}

Birinci dönemde okutulan dersler incelendiğinde, 73 işletme yönetimi bölümünde toplam 348 ders, toplamda 977 ders saati olarak okutulmaktadır. Araştırmaya dahil edilen 73 meslek yüksekokuluna ait işletme yönetimi bölümlerinin tamamında, "İşletme I" olarak sınıflandırılan dersler okutulmaktadır. Bu dersleri sırasıyla 71 ve 70 ders sayısıyla, "Muhasebe ve Finans I" ve "İktisat I" dersleri takip etmektedir. Temel olarak verilen bu derslerin yanında, "Hukuk I" (66 ders sayısıyla) sinıfina giren dersler bölümlerin tamamına yakınında verilmektedir. "Verilen Diğer Dersler I", Tablo 9'daki söz konusu sınıflandırmaların dışında kalan diğer derslerden oluşmakta ve haftalık en az 1 saat, en fazla ise 3 saat olarak okutulmaktadır. Birinci dönemde haftalık ders saati toplamı açısından, işletme yönetimi bölümlerinde en çok "Muhasebe ve Finans I" sınıflandırmasına ait dersler okutulmaktadır. Okutulan ders saatleri toplamına göre, "Muhasebe ve Finans I" sınıflandırmasındaki derslerin ağırlığı (243 toplam ders saatiyle) \%24,87'dir. Yani birinci dönemde okutulan derslerin ders saati bakımından dörtte birini muhasebe ve finans dersleri oluşturmaktadır. "Muhasebe ve Finans I" derslerini toplam ders saati bakımından sırasıyla, \%23,95; \%19,04 ve \%15,66 ile "İşletme I", "İktisat I" ve "Hukuk I" dersleri takip etmektedir. Özetle "Muhasebe ve Finans I", birinci dönemde toplam ders saati açısından $243(\% 24,87)$ ders saatiyle ilk sırada, ders sayısı açısından incelendiğinde ise $71(\% 20,40)$ ders ile ikinci sırada yer almaktadır. Ek olarak, "Muhasebe ve Finans I" dersleri en az 2 en çok ise 4 saat olarak okutulmaktadır.

Tablo 10. Birinci Dönem Haftalık Ders Saatlerine Göre Sıklık

\begin{tabular}{|c|c|c|c|c|c|c|c|c|}
\hline \multirow{3}{*}{$\begin{array}{c}\text { Sinıflandırılan } \\
\text { Dersler }\end{array}$} & \multicolumn{8}{|c|}{ Ders saatleri } \\
\hline & \multicolumn{2}{|c|}{1} & \multicolumn{2}{|c|}{2} & \multicolumn{2}{|c|}{3} & \multicolumn{2}{|c|}{4} \\
\hline & Sıklık & Yüzde & Sıklık & Yüzde & Sıklık & Yüzde & Sıklık & Yüzde \\
\hline İşletme I & - & - & 6 & 8,22 & 46 & 63,01 & 21 & 28,77 \\
\hline Muhasebe ve Finans I & - & - & 2 & 2,82 & 37 & 52,11 & 32 & 45,07 \\
\hline İktisat I & - & - & 27 & 38,57 & 40 & 57,14 & 3 & 4,29 \\
\hline Hukuk I & - & - & 47 & 71,21 & 17 & 25,76 & 2 & 3,03 \\
\hline Verilen Diğer Dersler I & 3 & 4,41 & 37 & 54,41 & 28 & 41,18 & - & - \\
\hline
\end{tabular}

Birinci dönemde İşletme I, Muhasebe ve Finans I ve İktisat I sınıflandırılmasında okutulan dersler çoğunlukla haftada üç ders saati olarak okutulmuştur. Dört saat okutulan derslerin ise büyük çoğunluğunu Muhasebe ve Finans I sınıflandırılmasına giren dersler oluşturmaktadır. 
Tablo 11. İkinci Dönem Ders ve Haftalık Ders Saatlerinin Dağılımı

\begin{tabular}{|c|c|c|c|c|c|c|c|}
\hline \multirow[b]{2}{*}{$\begin{array}{l}\text { Sinıflandırılan } \\
\text { Dersler }\end{array}$} & \multirow[b]{2}{*}{$\begin{array}{c}\text { Ders } \\
\text { Sayısı }\end{array}$} & \multicolumn{4}{|c|}{ Ders Saati } & \multirow{2}{*}{$\begin{array}{c}\text { Ders } \\
\text { Sayısının } \\
\text { Genel } \\
\text { Toplam } \\
\text { Ağırlığı } \\
\end{array}$} & \multirow{2}{*}{$\begin{array}{c}\text { Ders Saati } \\
\text { Toplamının } \\
\text { Genel Toplam } \\
\text { Ağırlığı }\end{array}$} \\
\hline & & Toplamı & En Az & $\begin{array}{c}\text { En } \\
\text { Fazla }\end{array}$ & Ortalaması & & \\
\hline Muhasebe ve Finans II & 69 & 240 & 2 & 4 & 3,48 & $20,47 \%$ & $26,46 \%$ \\
\hline İktisat II & 55 & 144 & 2 & 4 & 2,62 & $16,32 \%$ & $15,88 \%$ \\
\hline Hukuk II & 55 & 129 & 2 & 3 & 2,35 & $16,32 \%$ & $14,22 \%$ \\
\hline İstatistik & 39 & 88 & 2 & 3 & 2,26 & $11,57 \%$ & $9,7 \%$ \\
\hline İşletme II & 18 & 53 & 2 & 4 & 2,94 & $5,34 \%$ & $5,84 \%$ \\
\hline Yönetim & 13 & 36 & 2 & 3 & 2,77 & $3,86 \%$ & $3,97 \%$ \\
\hline Verilen Diğer Dersler II & 88 & 217 & 1 & 4 & 2,47 & $26,11 \%$ & $23,93 \%$ \\
\hline Genel Toplam & 337 & 907 & & & & & \\
\hline
\end{tabular}

İkinci dönemde verilen dersler incelendiğinde ise, incelenen 73 işletme yönetimi bölümünde toplam 337 ders toplamda 907 ders saati olarak okutulmaktadır. İkinci dönemde, en çok 69 ders sayısıyla "Muhasebe ve Finans II" olarak sınıflandırılan dersler okutulmaktadır. Bu dersleri sırasıyla 55, 55, 39, 18 ve 13 ders sayısıyla, “İktisat II”, "Hukuk II", "İstatistik”, "İşletme II" ve "Yönetim" dersleri takip etmektedir. "Verilen Diğer Dersler II”, Tablo 11'deki söz konusu sınıflandırmaların dışında kalan diğer derslerden oluşmakta ve haftalık en az 1 saat, en fazla ise 4 saat olarak okutulmaktadır. İkinci dönemde, haftalık ders saati toplamı açısından da işletme yönetimi bölümlerinde en çok "Muhasebe ve Finans II" sınıflandırmasına ait dersler okutulmaktadır. Okutulan ders saatleri toplamına göre, "Muhasebe ve Finans II" sınıflandırmasındaki derslerin ağırlığı (240 toplam ders saatiyle) \%26,46'dir. Yani ikinci dönemde de okutulan derslerin ders saati bakımından dörtte birini, muhasebe ve finans dersleri oluşturmaktadır. "Muhasebe ve Finans II" derslerini toplam ders saati bakımından sırasıyla, \%15,88; \%14,22; \%9,7; \%5,84 ve \%3,97 ile "İktisat II”, "Hukuk II”, “İstatistik”, “İşletme II” ve "Yönetim” dersleri takip etmektedir. Özetle "Muhasebe ve Finans II", ikinci dönemde toplam ders saati açısından $240(\% 26,46)$ ders saatiyle ilk sırada, ders sayısı açısından incelendiğinde ise $69(\% 20,47)$ ders ile yine ilk sirada yer almaktadır. Ek olarak, "Muhasebe ve Finans II” dersleri en az 2 en çok ise 4 saat olarak okutulmaktadır.

Tablo 12. İkinci Dönem Haftalık Ders Saatlerine Göre Sıklık

\begin{tabular}{|c|c|c|c|c|c|c|c|c|}
\hline \multirow{3}{*}{$\begin{array}{c}\text { Sinıflandırılan } \\
\text { Dersler }\end{array}$} & \multicolumn{8}{|c|}{ Ders saatleri } \\
\hline & \multicolumn{2}{|c|}{1} & \multicolumn{2}{|c|}{2} & \multicolumn{2}{|c|}{3} & \multicolumn{2}{|c|}{4} \\
\hline & Siklık & Yüzde & Siklık & Yüzde & Siklık & Yüzde & Siklık & Yüzde \\
\hline Muhasebe ve Finans II & - & - & 1 & 1,47 & 34 & 49,28 & 34 & 49,28 \\
\hline İktisat II & - & - & 22 & 40 & 32 & 58,18 & 1 & 1,82 \\
\hline Hukuk II & - & - & 36 & 65,45 & 19 & 34,55 & - & - \\
\hline İstatistik & - & - & 29 & 74,36 & 10 & 25,64 & - & - \\
\hline İşletme II & - & - & 2 & 11,11 & 15 & 83,33 & 1 & 5,56 \\
\hline Yönetim & - & - & 3 & 23,08 & 10 & 76,92 & - & - \\
\hline Verilen Diğer Dersler II & 1 & 1,14 & 49 & 55,68 & 34 & 38,64 & 4 & 4,55 \\
\hline
\end{tabular}

Haftalık ders saatleri sıklığında ise yine muhasebe finans derslerinin haftalık ders yüklerinin diğer derslere göre fazla olduğu ve derslerin çoğunlukla 3 ve 4 saat olarak okutulduğu tespit edilmiştir.

Tablo 13. Üçüncü Dönem Ders ve Haftalık Ders Saatlerinin Dağılımı

\begin{tabular}{|c|c|c|c|c|c|c|c|}
\hline \multirow{2}{*}{$\begin{array}{l}\text { Sinıflandırılan } \\
\text { Dersler }\end{array}$} & \multirow[b]{2}{*}{$\begin{array}{c}\text { Ders } \\
\text { Sayısı }\end{array}$} & \multicolumn{4}{|c|}{ Ders Saati } & \multirow{2}{*}{$\begin{array}{c}\text { Ders } \\
\text { Sayısının } \\
\text { Genel } \\
\text { Toplam } \\
\text { Ağırlığı }\end{array}$} & \multirow{2}{*}{$\begin{array}{c}\text { Ders Saati } \\
\text { Toplamının } \\
\text { Genel Toplam } \\
\text { Ağırlığı }\end{array}$} \\
\hline & & Toplamı & En Az & En Fazla & Ortalaması & & \\
\hline Muhasebe ve Finans III & 118 & 388 & 2 & 4 & 3,28 & $32,07 \%$ & $36,47 \%$ \\
\hline Pazarlama & 52 & 147 & 2 & 4 & 2,83 & $14,13 \%$ & $13,82 \%$ \\
\hline Yönetim Organizasyon & 50 & 139 & 2 & 4 & 2,78 & $13,59 \%$ & $13,06 \%$ \\
\hline Hukuk III & 22 & 57 & 2 & 4 & 2,59 & $5,98 \%$ & $5,36 \%$ \\
\hline Dış Ticaret İşlemleri & 19 & 39 & 2 & 3 & 2,05 & $5,16 \%$ & $3,67 \%$ \\
\hline Halkla İlişkiler & 13 & 35 & 2 & 4 & 2,69 & $3,53 \%$ & $3,29 \%$ \\
\hline İnsan Kaynakları & 12 & 33 & 2 & 3 & 2,75 & $3,26 \%$ & $3,10 \%$ \\
\hline Üretim Yönetimi & 10 & 30 & 2 & 4 & 3 & $2,72 \%$ & $2,82 \%$ \\
\hline Örgütsel Davranıș & 8 & 21 & 2 & 3 & 2,62 & $2,17 \%$ & $1,97 \%$ \\
\hline Verilen Diğer Dersler III & 64 & 175 & 2 & 6 & 2,73 & $17,39 \%$ & $16,45 \%$ \\
\hline Genel Toplam & 368 & 1064 & & & & & \\
\hline
\end{tabular}

Üçüncü dönemde verilen dersler incelendiğinde ise, incelenen 73 işletme yönetimi bölümünde toplam 368 ders toplamda 1064 ders saati olarak okutulmaktadır. Üçüncü dönemde, en çok 118 ders sayısıyla "Muhasebe ve Finans III" olarak sınıflandırılan dersler okutulmaktadır. Bu dersleri sirasılla 52, 50, 22, 19, 13, 12, 10 ve 8 ders sayısıla, "Pazarlama", "Yönetim 
Organizasyon”, “Hukuk III”, “D1ş Ticaret İşlemleri”, "Halkla İlişkiler”, “İnsan Kaynakları”, “Üretim Yönetimi” ve “Örgütsel Davranış" dersleri takip etmektedir. "Verilen Diğer Dersler III”, Tablo 13'deki söz konusu sınıflandırmaların dıșında kalan diğer derslerden oluşmakta ve haftalık en az 2 saat, en fazla ise 6 saat olarak okutulmaktadır. Üçüncü dönemde, haftalık ders saati toplamı açısından da işletme yönetimi bölümlerinde en çok "Muhasebe ve Finans III" sınıflandırmasına ait dersler okutulmaktadır. Okutulan ders saatleri toplamına göre, "Muhasebe ve Finans III” sınıflandırmasındaki derslerin ağırlığı (388 toplam ders saatiyle) \%36,47'dir. Yani üçüncü dönemde okutulan derslerin ders saati bakımından üçte birini, muhasebe ve finans dersleri oluşturmaktadır. Özetle "Muhasebe ve Finans III", üçüncü dönemde toplam ders saati açısından 388 (\%36,47) ders saatiyle ilk sırada, ders sayısı açısından incelendiğinde ise $118(\% 32,07)$ ders ile yine ilk sırada yer almaktadır. Ek olarak, "Muhasebe ve Finans III” dersleri en az 2 en çok ise 4 saat olarak okutulmaktadır. Ayrıca, üçüncü dönemde verilen muhasebe ve finans derslerinin sayısı diğer dönemlere göre artmış ve bu durum dönem içindeki ağırlığını da artırmıştır.

Tablo 14. Üçüncü Dönem Haftalık Ders Saatlerine Göre Sıklık

\begin{tabular}{|c|c|c|c|c|c|c|c|c|}
\hline \multirow{3}{*}{$\begin{array}{c}\text { Sinıflandırılan } \\
\text { Dersler }\end{array}$} & \multicolumn{8}{|c|}{ Ders saatleri } \\
\hline & \multicolumn{2}{|c|}{2} & \multicolumn{2}{|c|}{3} & \multicolumn{2}{|c|}{4} & \multicolumn{2}{|c|}{6} \\
\hline & Sıklık & Yüzde & Sıklık & Yüzde & Sıklık & Yüzde & Sıklık & Yüzde \\
\hline Muhasebe ve Finans III & 10 & 8,47 & 64 & 54,24 & 44 & 37,29 & - & - \\
\hline Pazarlama & 10 & 19,23 & 41 & 78,85 & 1 & 1,92 & - & - \\
\hline Yönetim Organizasyon & 15 & 30 & 31 & 62 & 4 & 8 & - & - \\
\hline Hukuk III & 11 & 50 & 9 & 40,91 & 2 & 9,09 & - & - \\
\hline Dış Ticaret İşlemleri & 18 & 94,74 & 1 & 5,26 & - & - & - & - \\
\hline Halkla İlişkiler & 6 & 46,15 & 5 & 38,46 & 2 & 15,38 & - & - \\
\hline İnsan Kaynakları & 3 & 25 & 9 & 75 & - & - & - & - \\
\hline Üretim Yönetimi & 2 & 20 & 6 & 60 & 2 & 20 & - & - \\
\hline Örgütsel Davranıș & 3 & 37,5 & 5 & 62,5 & - & - & - & - \\
\hline Verilen Diğer Dersler III & 27 & 42,19 & 29 & 45,31 & 7 & 10,94 & 1 & 1,56 \\
\hline
\end{tabular}

Ders sıklığı açısından üçüncü dönemde yine muhasebe finans derslerinin haftalık ders saati yükünün diğer derslere göre daha fazla olduğu tespit edilmiştir.

Tablo 15. Dördüncü Dönem Ders ve Haftalık Ders Saatlerinin Dağılımı

\begin{tabular}{|c|c|c|c|c|c|c|c|}
\hline \multirow[b]{2}{*}{$\begin{array}{l}\text { Sinıflandırılan } \\
\text { Dersler }\end{array}$} & \multirow[b]{2}{*}{$\begin{array}{l}\text { Ders } \\
\text { Sayısı }\end{array}$} & \multicolumn{4}{|c|}{ Ders Saati } & \multirow[b]{2}{*}{$\begin{array}{c}\text { Ders Sayısının } \\
\text { Genel Toplam } \\
\text { Ağırlığı }\end{array}$} & \multirow{2}{*}{$\begin{array}{c}\text { Ders Saati } \\
\text { Toplamının } \\
\text { Genel Toplam } \\
\text { Ağırlığı }\end{array}$} \\
\hline & & Toplamı & $\begin{array}{l}\text { En } \\
\text { Az }\end{array}$ & $\begin{array}{l}\text { En } \\
\text { Fazla }\end{array}$ & Ortalaması & & \\
\hline Muhasebe ve Finans IV & 53 & 157 & 2 & 4 & 2,96 & $16,93 \%$ & $15,83 \%$ \\
\hline İnsan Kaynakları Yönetimi & 42 & 126 & 2 & 4 & 3 & $13,42 \%$ & $12,70 \%$ \\
\hline Üretim Yönetimi & 41 & 122 & 2 & 4 & 2,97 & $13,10 \%$ & $12,30 \%$ \\
\hline Girișimcilik & 38 & 131 & 2 & 4 & 3,44 & $12,14 \%$ & $13,21 \%$ \\
\hline Hukuk Dersleri IV & 37 & 103 & 2 & 4 & 2,78 & $11,82 \%$ & $10,38 \%$ \\
\hline Pazarlama & 23 & 62 & 2 & 4 & 2,69 & $7,35 \%$ & $6,25 \%$ \\
\hline Yönetim Organizasyon & 15 & 42 & 2 & 4 & 2,8 & $4,79 \%$ & $4,23 \%$ \\
\hline Türk Vergi Sistemi & 9 & 27 & 2 & 4 & 3 & $2,88 \%$ & $2,72 \%$ \\
\hline Örgütsel Davranış & 7 & 20 & 2 & 4 & 2,86 & $2,24 \%$ & $2,02 \%$ \\
\hline Verilen Diğer Dersler IV & 48 & 202 & 2 & 5 & 2,60 & $15,34 \%$ & $20,36 \%$ \\
\hline Genel Toplam & 313 & 992 & & & & & \\
\hline
\end{tabular}

Dördüncü dönemde verilen dersler incelendiğinde ise, incelenen 73 işletme yönetimi bölümünde toplam 313 ders toplamda 992 ders saati olarak okutulmaktadır. Dördüncü dönemde, en çok 53 ders sayısıyla "Muhasebe ve Finans IV" olarak sınıflandırılan dersler okutulmaktadır. Bu dersleri sırasıyla 42, 41, 38, 37, 23, 15, 9 ve 7 ders sayısıyla, "İnsan Kaynakları Yönetimi”, "Üretim Yönetimi”, "Girișimcilik”, "Hukuk Dersleri IV”, "Pazarlama", "Yönetim Organizasyon”, "Türk Vergi Sistemi" ve "Örgütsel Davranış" dersleri takip etmektedir. "Verilen Diğer Dersler IV", Tablo 15'deki söz konusu sınıflandırmaların dışında kalan diğer derslerden oluşmakta ve haftalık en az 2 saat, en fazla ise 5 saat olarak okutulmaktadır. Dördüncü dönemde, haftalık ders saati toplamı açısından da işletme yönetimi bölümlerinde en çok "Muhasebe ve Finans IV" sinıflandırmasına ait dersler okutulmaktadır. Okutulan ders saatleri toplamına göre, "Muhasebe ve Finans IV" sınıflandırmasındaki derslerin ağırlığı (157 toplam ders saatiyle) \%15,83'tür. Yani dördüncü dönemde okutulan derslerin ders saati bakımından beşte birinden daha fazlasını, muhasebe ve finans dersleri oluşturmaktadır. Özetle "Muhasebe ve Finans IV", dördüncü dönemde toplam ders saati açısından $157(\% 15,83)$ ders saatiyle ilk sırada, ders sayısı açısından incelendiğinde ise $53(\% 16,93)$ ders ile yine ilk sırada yer almaktadır. Ek olarak, "Muhasebe ve Finans IV" dersleri en az 2 en çok ise 4 saat olarak okutulmaktadır. Ayrıca, İşletme yönetimi bölümünün dördüncü dönemde zorunlu ders çeşitliliği diğer dönemlere göre artmıştır. $\mathrm{Bu}$ dersler içinde muhasebe finans derslerinin toplam ders saat ağırlığı ilk üç dönemde olduğu gibi diğer derslere göre daha fazladir. 
Tablo 16. Dördüncü Dönem Haftalık Ders Saatlerine Göre Sıklık

\begin{tabular}{|c|c|c|c|c|c|c|c|c|}
\hline \multirow{3}{*}{$\begin{array}{c}\text { Sinıflandırılan } \\
\text { Dersler }\end{array}$} & \multicolumn{8}{|c|}{ Ders saatleri } \\
\hline & \multicolumn{2}{|c|}{2} & \multicolumn{2}{|c|}{3} & \multicolumn{2}{|c|}{4} & \multicolumn{2}{|c|}{5} \\
\hline & Sıklık & Yüzde & Sıklık & Yüzde & Sıklık & Yüzde & Sıklık & Yüzde \\
\hline Muhasebe ve Finans IV & 14 & 26,42 & 27 & 50,94 & 12 & 22,64 & - & - \\
\hline İnsan Kaynakları Yönetimi & 4 & 9,52 & 34 & 80,95 & 4 & 9,52 & - & - \\
\hline Üretim Yönetimi & 10 & 24,39 & 22 & 53,66 & 9 & 21,95 & - & - \\
\hline Girişimcilik & 4 & 10,53 & 13 & 34,21 & 21 & 55,26 & - & - \\
\hline Hukuk Dersleri IV & 16 & 43,24 & 13 & 35,14 & 8 & 21,62 & - & - \\
\hline Pazarlama & 9 & 39,13 & 12 & 52,17 & 2 & 8,7 & - & - \\
\hline Yönetim Organizasyon & 5 & 33,33 & 8 & 53,33 & 2 & 13,33 & - & - \\
\hline Türk Vergi Sistemi & 3 & 33,33 & 3 & 33,33 & 3 & 33,33 & - & - \\
\hline Örgüitsel Davranıs & 1 & 14,29 & 6 & 85,71 & - & - & - & - \\
\hline Verilen Diğer Dersler IV & 25 & 52,08 & 18 & 37,50 & 4 & 8,33 & 1 & 2,08 \\
\hline
\end{tabular}

Son dönem haftalık ders saatlerinin sıklığında ise, girişimcilik sınıflandırmasına giren derslerin ağırlıkla 4 saat okutulduğu, muhasebe ve finans derslerinin ise ağırlıklı olarak 3 saat okutulduğu tespit edilmiştir.

Tablo 17. Tüm Derslerin Genel Değerlendirilmesi

\begin{tabular}{|c|c|c|c|c|c|c|c|}
\hline \multirow[b]{2}{*}{$\begin{array}{l}\text { Sinıflandırılan } \\
\text { Dersler }\end{array}$} & \multirow{2}{*}{$\begin{array}{c}\text { Ders } \\
\text { Sayısı }\end{array}$} & \multicolumn{4}{|c|}{ Ders Saati } & \multirow{2}{*}{$\begin{array}{c}\text { Ders } \\
\text { Sayısının } \\
\text { Genel } \\
\text { Toplam } \\
\text { Ağırlığı } \\
\end{array}$} & \multirow{2}{*}{$\begin{array}{c}\text { Ders Saati } \\
\text { Toplamının } \\
\text { Genel Toplam } \\
\text { Ağırlığı }\end{array}$} \\
\hline & & Toplamı & $\operatorname{En} A z$ & En Fazla & Ortalama & & \\
\hline Muhasebe ve Finans & 311 & 1028 & 2 & 4 & 3,30 & $22,77 \%$ & $26,61 \%$ \\
\hline Hukuk & 180 & 442 & 2 & 4 & 2,45 & $13,18 \%$ & $11,44 \%$ \\
\hline İktisat & 135 & 357 & 2 & 4 & 2,64 & $9,88 \%$ & $9,24 \%$ \\
\hline Pazarlama & 94 & 263 & 2 & 4 & 2,80 & $6,88 \%$ & $6,81 \%$ \\
\hline Genel İşletme & 92 & 290 & 2 & 4 & 3,15 & $6,73 \%$ & $7,51 \%$ \\
\hline Yönetim Organizasyon & 82 & 230 & 2 & 4 & 2,80 & $6,00 \%$ & $5,95 \%$ \\
\hline İnsan Kaynakları & 64 & 177 & 1 & 4 & 2,77 & $4,69 \%$ & $4,58 \%$ \\
\hline Üretim Yönetimi & 56 & 164 & 2 & 4 & 2,93 & $4,10 \%$ & $4,25 \%$ \\
\hline İstatistik & 50 & 119 & 2 & 4 & 2,38 & $3,66 \%$ & $3,08 \%$ \\
\hline Girişimcilik & 49 & 161 & 2 & 4 & 3,29 & $3,59 \%$ & $4,17 \%$ \\
\hline Örgütsel Davranış & 24 & 65 & 2 & 3 & 2,71 & $1,76 \%$ & $1,68 \%$ \\
\hline Halka İlişkiler & 22 & 56 & 2 & 4 & 2,54 & $1,61 \%$ & $1,45 \%$ \\
\hline D1ş Ticaret İşlemleri & 19 & 39 & 2 & 3 & 2,05 & $1,39 \%$ & $1,01 \%$ \\
\hline Verilen Diğer Dersler & 188 & 472 & 1 & 6 & 2,51 & $13,76 \%$ & $12,22 \%$ \\
\hline Genel Toplam & 1366 & 3863 & & & & & \\
\hline
\end{tabular}

Tablo 17'de tüm dönemlerde okutulan derslere ait genel bir değerlendirme yapılabilmek için, dersler tekrar sınıflandırılmıştır. Buna göre 73 işletme yönetimi bölümünün dört döneminde, toplam 1366 ders okutulmakta ve bu derslerin 311'ini muhasebe ve finans dersleri oluşturmaktadır. Muhasebe ve finans derslerinin haftalık ders yükünün, okutulan diğer derslere göre en yüksek (ders saati ortalaması 3,30) olduğu tespit edilmiştir. Ders saati açısından incelendiğinde ise, muhasebe ve finans derslerinin ders saat toplamı 1028'dir ve bu dört dönemin ders saatleri toplamının \%26,61'ini oluşturmaktadır.

\section{SONUÇ VE ÖNERILER}

Küreselleşen dünyada, ticari kuruluş ve endüstriler sürekli bir değişim içerisindedir. Bu değişim süreci, geleneksel konularda bilgili, teknik ve bireysel iş becerilerine sahip yöneticilere ve personele olan ihtiyacı arttırmıştır. Bu noktada, doğru, etkin ve kaliteli bilgiye zamanında ulaşmak büyük öneme sahip bir konu haline gelmiştir.

Bir bilgi sistemi olan muhasebe ve finans, karar alıcıların doğru bilgilere ulaşmasında büyük bir önem arz etmektedir. Bu önemin bir gereği olarak, muhasebe ve finansa ilişkin işlemlerin doğru bir şekilde kavranması ve uygulanabilmesi için kaliteli bir eğitim sistemi oluşturmak gerekmektedir. Ancak, muhasebe ve finans alanında kaliteli bir eğitim sistemi oluşturmak için dünyaca kabul edilmiş ortak bir standart bulunmamaktadır. Farklı ülke ve üniversitelerde, muhasebe ve finans derslerinin içerik, düzey ve kalitesi bakımından birçok farklılık bulunmaktadır. Bu çalıșmada, araştırma kapsamında ele alınan İșletme Yönetimi Bölümlerinin birinci döneminde, "Muhasebe ve Finans I" olarak sınıflandırılan derslerin toplam ders saati açısından 243 $(\% 24,87)$ ders saatiyle ilk sırada, ders sayısı açısından incelendiğinde ise $71(\% 20,40)$ ders ile ikinci sırada yer aldığ 1 ve ek olarak, "Muhasebe ve Finans I" derslerinin en az 2 en çok ise 4 saat olarak okutulduğu tespit edilmiştir. Ayrıca, İşletme Yönetimi Bölümlerinin birinci döneminde, toplam 348 ders, 977 ders saati olarak okutulmaktadır. Bu 348 dersin 71 'i, 977 ders saatinin ise 243 'ü muhasebe finans derslerine aittir. Bu sonuçlar, birinci dönemde İşletme Yönetimi Bölümlerinde okutulan derslerin dörtte birinin muhasebe ve finans dersleri olduğunu açıkça göstermektedir. 
İkinci dönemde "Muhasebe ve Finans II", toplam ders saati açısından $240(\% 26,46)$ ders saatiyle ilk sırada, ders sayısı açısından incelendiğinde ise $69(\% 20,47)$ ders ile yine ilk sırada yer almaktadır ve ek olarak, "Muhasebe ve Finans II" dersleri en az 2 en çok ise 4 saat olarak okutulmaktadır. Ayrıca, İşletme Yönetimi Bölümlerinin ikinci döneminde, toplam 337 ders, 907 ders saati olarak okutulmaktadır. Bu 337 dersin 69'u, 907 ders saatinin ise 240'1 muhasebe finans derslerine aittir. Bu sonuçlar, ikinci dönemde de İşletme Yönetimi Bölümlerinde okutulan derslerin dörtte birinin muhasebe ve finans dersleri olduğunu açıça göstermektedir.

Üçüncü dönemde "Muhasebe ve Finans III", toplam ders saati açısından $388(\% 36,47)$ ders saatiyle ilk sırada, ders sayıs1 açısından incelendiğinde ise $118(\% 32,07)$ ders ile yine ilk sırada yer almaktadır ve ek olarak, "Muhasebe ve Finans III" dersleri en az 2 en çok ise 4 saat olarak okutulmaktadır. Ayrıca, İşletme Yönetimi Bölümlerinin üçüncü döneminde, toplam 368 ders, 1064 ders saati olarak okutulmaktadır. Bu 368 dersin 118'i, 1064 ders saatinin ise 388'i muhasebe finans derslerine aittir. Bu sonuçlar, üçüncü dönemde de İşletme Yönetimi Bölümlerinde okutulan derslerin üçte birinin muhasebe ve finans dersleri olduğunu açıkça göstermiş ve söz konusu dönemde verilen muhasebe ve finans derslerinin sayısı diğer dönemlere göre hem sayı hem de ağırlık bakımından artmıştır.

Dördüncü ve son dönemde "Muhasebe ve Finans IV", toplam ders saati açısından $157(\% 15,83)$ ders saatiyle ilk sırada, ders sayısı açısından incelendiğinde ise $53(\% 16,93)$ ders ile yine ilk sırada yer almaktadır ve ek olarak, "Muhasebe ve Finans IV" dersleri en az 2 en çok ise 4 saat olarak okutulmaktadır. Ayrıca, İşletme Yönetimi Bölümlerinin dördüncü döneminde, toplam 313 ders, 992 ders saati olarak okutulmaktadır. Bu 313 dersin 53'ü, 992 ders saatinin ise 157'si muhasebe finans derslerine aittir. Bu sonuçlar, dördüncü dönem içinde de muhasebe finans derslerinin toplam ders saat ağırlığının ilk üç dönemde olduğu gibi diğer derslere göre daha fazla olduğunu göstermektedir. Dördüncü dönemde zorunlu ders çeşitliliğinin diğer dönemlere göre arttığı da yapılan incelemeler sonucunda elde edilmiştir. Çalışmanın sonuçları tüm dönemleri içerecek şekilde ele alındığında ise, 73 işletme yönetimi bölümünde toplam 1366 ders okutulmakta ve bu derslerin 311'ini muhasebe ve finans dersleri oluşturmaktadır. Muhasebe ve finans derslerinin haftalık ders yükünün, okutulan diğer derslere göre en yüksek olduğu tespit edilmiştir. Ders saati açısından incelendiğinde ise, muhasebe ve finans derslerinin ders saat toplamı 1028'dir ve bu dört dönemin ders saatleri toplamının \%26,61'ini oluşturmaktadır.

Terzi, Şen ve Solak (2013) çalışmalarında, işletme lisans bölümleri muhasebe derslerine yeterli bir oranda zorunlu ders olmadığını, bunun yanı sıra seçmeli derslerde ise çok daha yetersiz kaldığını da tespit etmişlerdir. Fakat bu çalışma sonucunda önlisans programlarının zorunlu derslerinin büyük bir bölümü muhasebe ve finans derslerini kapsadığı tespit edilmiştir.

Subaş1 ve Demir (2009), lisans bölümlerinde zorunlu muhasebe dersi veren üniversiteler incelendiğinde devlet üniversitelerinin büyük çoğunluğunun tüm öğretim yıllarında zorunlu muhasebe dersi açtığını tespit etmişlerdir. Önlisans programlarını inceleyen bu çalışmada da incelenen tüm üniversitelerde muhasebe ve finans derslerinin tüm öğretim dönemlerinde zorunlu olarak açıldığı tespit edilmiştir. Sonuç olarak bu çalışmada ulaşılan sonuçlar ile Terzi, Şen ve Solak (2013)'ın ve Subaşı ve Demir (2009)'in yapmış oldukları çalışmanın sonuçları ile benzerlikler göstermekle birlikte bu çalışma, işletme yönetimi önlisans programlarını dikkate alması ve ders sayılarıyla beraber, okutulan tüm derslerin incelenmesi açısından farklılık taşımaktadır.

Çalışma sonucunda elde edilen bulgular özetlenecek olursa, Türkiye'deki İşletme Yönetimi Bölümlerinin tüm dönemlerinde en çok okutulan zorunlu derslerin muhasebe ve finans alanına ait derslerden oluştuğu tespit edilmiştir. Çalışmada elde edilen sonuçlar, Türkiye'deki İşletme Yönetimi Bölümlerinin muhasebe ve finans alanında yeterince derse yer verdikleri ve muhasebe ve finans eğitiminin doğru, etkin ve kaliteli olarak değerlendirilebileceği şeklinde yorumlanabilir. Türkiye'deki İşletme Yönetimi Bölümlerinin, uygulamalı ve sahada muhasebe ve finans eğitimlerine de yer vererek, bu kaliteyi çok daha fazla arttırabileceği yönünde bir öneride bulunulabilir. Ayrıca yapılan çalışmada sadece zorunlu dersler dikkate alınmıştır. Bundan sonraki çalışmalarda seçmeli derslerde analize dahil edilerek derslere daha geniş bir çerçeveden bakılabilir.

\section{KAYNAKÇA (REFERENCES)}

Brown, A., \& Rich, M. (2020). Pedagogy and Evaluation: The Challenge for Business and Management Degree Courses in the 21st Century. The Electronic Journal of Business Research Methods, 18 (2), 84-99.

Çürük, T., \& Doğan, Z. (2001). Muhasebe Eğitiminin İşletmelerin Taleplerini Karş1lama Düzeyi: Türkiye Örneği. ODTÜ Gelişme Dergisi, 28 (3-4), 281-310.

Heilporn, G., \& Desrochers, M.-E. (2020). Students' Learning Support and Perceptions in an Online Mathematics Course in a Business Faculty. The Canadian Journal for the Scholarship of Teaching and Learning, 11 (1), Article 5.

Kipping, M., Üsdiken, B., \& Puig, N. (2004). Imitation, Tension and Hybridization: Multiple "Americanizations Management Education in Mediterranean Europe". Journal of Management Inquiry, 13 (2).

Miah, S. J., \& Solomonides, I. (2021). Design Requirements of a Modern Business Master's Degree Course: Perspectives of Industry Practitioners. Education and Information Technologies (2021) 26, 763-781. 
Özkul, A. S. (2012). 19. Yüzyıl Türk Yükseköğretiminde İşletme Eğitimi. Süleyman Demirel Üniversitesi Sosyal Bilimler Enstitüsü Dergisi, 2012/2, Sayl:16, 223-241.

Sargut, A. S. (2009). Türkiye'de İşletme Yönetimi Eğitiminin Kurumsal Çerçevesi: Çeşitlilikten Eşbiçimliliğe, Eskişehir Osmangazi Üniversitesi İIBF Dergisi, Nisan 2009, 4 (1), 51-63.

Subaşı, Ş., \& Demir, B. (2009). Fakültelerin İşletme Bölümlerinde Verilen Muhasebe Derslerinin Durum Analizi. Muhasebe ve Finansman Dergisi, 2009, Sayl 44, 127-137.

Teker, S. (1998). İşletmecilik Eğitiminde Dünya Standartlarına Ulaşılması. 6. İşletmecilik Kongresi Bildiri Kitabı, Akdeniz Üniversitesi İktisadi ve İdari Bilimler Fakültesi, 12-14 Kasım.

Terzi, S., Şen, İ. K., \& Solak, B. (2013). Bologna Sürecinin Muhasebe Eğitimine Etkisi: Üniversitelerin İşletme Bölümlerinin Ders Programları Üzerine Bir İnceleme. Muhasebe ve Finansman Dergisi Temmuz 2013, 83-100.

Ünal, O., \& Doğanay, M. (2009). Lisans Düzeyindeki Muhasebe Eğitiminin Etkinliği: Sayıştay Özelinde Ampirik Bir Çalışma. Sayıştay Dergisi Sayı 74-75, Temmuz-Aralık 2009, 117-138.

Üsdiken, B. (2003). Türkiye'de İş Yapmanın ve İşletmenin Akademikleştirilmesi, 1930-1950. Ankara Üniversitesi Siyasal Bilgiler Fakültesi Dergisi, 58 (1), 119-147.

Yelkikalan, N., \& Pazarcık, Y. (2005). İşletme Eğitiminde Global Perspektif: ÇOMÜ BİGA İ.İ.B.F. Örneği. Selçuk Üniversitesi Karaman İktisadi ve İdari Bilimler Dergisi, 2 (5), 1-20.

Yüksek Öğretim Kurumu (2021). İşletme Yönetimi Programı Bulunan Tüm Üniversiteler, İşletme Yönetimi Programı Bulunan Tüm Üniversiteler, https://yokatlas.yok.gov.tr/onlisans-program.php?b=30009. (Erişim Tarihi: 01.02.2021).

Yüksel, A. S. (1998). İşletme Öğretiminde Evrim ve İlgi Çekici Sentez Örneği: Ali Haydar Aksoy. Marmara Üniversitesi Sosyal Bilimler Enstitüsü Öneri Dergisi, 2 (9), 15-16.

Zaif, F., \& Ayanoğlu, Y. (2007). Muhasebe Eğitiminde Kalitenin Arttırılmasında Ders Programlarının Önemi: Türkiye'de Bir İnceleme. Gazi Üniversitesi İktisadi ve İdari Bilimler Fakültesi Dergisi, 9 (1), 115-136. 
